\title{
Monitoring effecten zandsuppletie Leuvenumse beek 2017
}

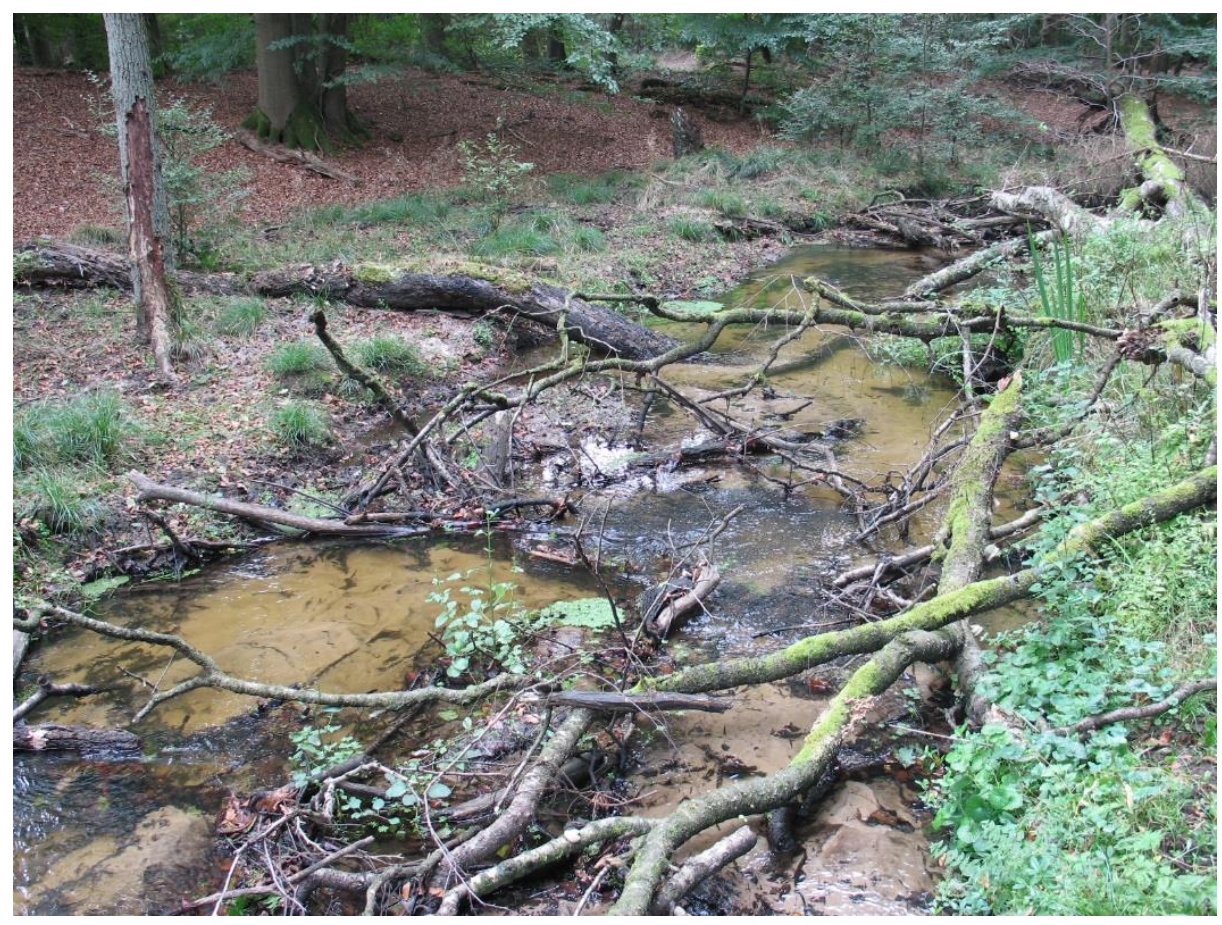

Ralf Verdonschot \& Piet Verdonschot

Notitie Zoetwatersystemen, Wageningen Environmental Research

December 2017 


\section{Auteurs \\ Ralf Verdonschot, Piet Verdonschot}

\section{Opdrachtgever}

Waterschap Vallei en Veluwe; contactpersoon Maarten Veldhuis

\section{Projectgroep}

Maarten Veldhuis, Christian Huising, Peter van Beers, Marcel Timmer, Jaap Petersen (Waterschap Vallei en Veluwe); Peter Dam, Mirte Kruit, Wijnand Francke (Natuurmonumenten)

\section{Referaat}

Verdonschot, R.C.M., Verdonschot P.F.M. (2017) Monitoring effecten zandsuppletie Leuvenumse beek 2017. Notitie Zoetwatersystemen, Wageningen Environmental Research, Wageningen UR, Wageningen.

\section{Trefwoorden}

beekherstel, Hierdense beek, laaglandbeek, loopkevers, spinnen, vegetatie, kleinschalige maatregelen

\section{Beeldmateriaal \\ Ralf Verdonschot}

\section{ISBN}

978-94-6343-566-6

\section{DOI}

https://doi.org/10.18174/467151

Dit onderzoek is ondersteund door het 'Innovatielab Building with Nature voor regionale wateren' (KB-24-001-007).

\section{(C) 2017 Wageningen Environmental Research, Wageningen UR}

- Overname, verveelvoudiging of openbaarmaking van deze uitgave is toegestaan mits met duidelijke bronvermelding.

- Overname, verveelvoudiging of openbaarmaking is niet toegestaan voor commerciële doeleinden en/of geldelijk gewin.

- Overname, verveelvoudiging of openbaarmaking is niet toegestaan voor die gedeelten van deze uitgave waarvan duidelijk is dat de auteursrechten liggen bij derden en/of zijn voorbehouden.

Alterra aanvaardt geen aansprakelijkheid voor eventuele schade voortvloeiend uit het gebruik van de resultaten van dit onderzoek of de toepassing van de adviezen 


\section{Inhoud}

$\begin{array}{ll}\text { Samenvatting } & 3\end{array}$

$1 \quad$ Inleiding en doel 4

2 Methode 5

2.1 Dwarsprofieltransectmetingen 5

$\begin{array}{lll}2.2 & \text { Flora en fauna van de oeverzones } & 7\end{array}$

3. Resultaten en discussie 9

3.1 Dwarsprofieltransectmetingen 9

3.2 Oever- en watervegetatie 14

3.3 Semi-terrestrische fauna: loopkevers en spinnen 18

4. Conclusies 21

5. Aanbevelingen 22

$\begin{array}{ll}\text { Literatuur } & 23\end{array}$

Bijlage 1: dwarsprofielen van alle suppletielocaties 24 


\section{Samenvatting}

In de Leuvenumse beek wordt vanaf 2014 het suppleren van zand als beekherstelmaatregel toegepast door Waterschap Vallei en Veluwe en Natuurmonumenten. Omdat over deze relatief nieuwe maatregel nog niet veel kennis voorhanden is, worden sindsdien de hydromorfologische en biologische ontwikkelingen gevolgd. In 2017 zijn in een aantal suppletietrajecten metingen verricht aan het profiel van de beekbodem en is de vegetatiesamenstelling en het voorkomen van semi-terrestrische ongewervelden (loopkevers, spinnen) van verschillende typen beekbegeleidende zones vastgelegd.

Op drie locaties is gemeten hoe het beekprofiel door de suppleties is veranderd ten opzichte van de uitgangssituatie. De metingen zijn verricht na het staken van de suppleties op deze locaties, in april en september 2017, ongeveer 2 jaar na de laatste suppletie. Ook is gemeten in het traject direct bovenstrooms van de eerste suppletielocatie. Het bleek dat twee va nde drie locaties min of meer in evenwicht waren en dat zandverplaatsing vooral nog benedenstrooms suppletielocatie Z2 voorkwam.

Om de ontwikkeling van de oeverzone na zandsuppletie vast te leggen zijn 6 trajecten van 50 meter lengte onderzocht in juni 2017, plus 1 controletraject in het droge bos op enige afstand van de beek. Deze trajecten hebben verschillende typen oevers. Er werd onderscheid gemaakt tussen: ingesneden gekanaliseerd (oorspronkelijke situatie), permanent nat beekmoeras (bovenstrooms Z1), beek met overstromingszones (winter nat, maar 's zomers onder invloed beek, benedenstrooms Z1) en zandbanken in het oorspronkelijke beekprofiel (Z2, Z3).

Er was sprake van massale ontwikkeling van moerasvegetatie in het beekmoeras en in de overstromingszones, waarschijnlijk naast de vernatting ook veroorzaakt door het afsterven van bomen. Het gaat veelal om algemene soorten van natte tot vochtige voedselrijke omstandigheden die al in het gebied aanwezig waren, vaak ook soorten van gestoorde (omgewoelde) bodems. Op beide plekken zijn ook zaailingen aangetroffen van beekbegeleidende bomen. Het is te verwachten dat de toename van moerasvegetatie een belangrijke functie heeft voor het gebied, door de grote bloemrijkdom is het aantrekkelijk voor bloembezoekende insecten en het levert ook voedsel op voor grote zoogdieren.

Het beekmoeras bleek een hotspot van ongewerveldenbiodiversiteit te zijn, met veel loopkever- en wolfsspinnensoorten die niet op andere typen oevers zijn aangetroffen. Echte beeksoorten, die te verwachten waren op bijvoorbeeld de zandbanken langs de beek, ontbraken vooralsnog. 


\section{$1 \quad$ Inleiding en doel}

Het beekherstel in de Hierdense beek is gericht op herstel en ontwikkeling van een zo natuurlijk mogelijk functionerend beeksysteem in het gehele beekdal van de Hierdense/Leuvenumse beek over een lengte van circa veertien kilometer (traject tussen landgoed Staverden en de monding in het Veluwemeer). Ondanks extensief beheer en de aanwezigheid van bos- en natuurgebied in en rond het beekdal van de Hierdense/Leuvenumse beek zijn er namelijk diverse knelpunten aanwezig op het gebied van de ecologie, morfologie, afvoerregime en waterkwaliteit, die het natuurlijk functioneren en daarmee de doelrealisatie in de weg staan.

Om deze knelpunten aan te pakken zijn de afgelopen jaren kleinschalige maatregelen genomen op het gebied van:

i) natuurvriendelijke inrichting van de beek en directe omgeving,

ii) natuurvriendelijk onderhoud in de beek,

iii) herstel van een natuurlijk afvoerregime (inclusief inundatiezones),

iv) het verbeteren van de ecologische kwaliteit van het gehele beekdal (o.a. antiverdrogingsmaatregelen).

Bouwen-met-natuur ('Building with nature') principes waren leidend bij de maatregelkeuze: zo veel mogelijk gebruik maken van of aansluiten op natuurlijke processen in de beek.

Eén van de toegepaste maatregelen was het gericht suppleren van zand in combinatie met het inbrengen van dood hout in het traject in het Leuvenumse bos. Het bezanden van een beek is een relatief nieuwe maatregel waarover nog niet veel kennis bestaat. Om de effecten van zandsuppletie op de ecologie en morfologie in kaart te brengen en eventueel bij te kunnen sturen wanneer dit noodzakelijk zou zijn, zijn vanaf 2014 door Wageningen Environmental Research metingen uitgevoerd om de korte-termijn-effecten in kaart te brengen (Verdonschot et al., 2016a, 2017). De belangrijkste inzichten van dit onderzoek zijn dat:

i) door het suppleren van zand het mogelijk is een ingesneden gekanaliseerde beek om te vormen naar een veel natuurlijkere beek waarbij de laagtes in het beekdal in verbinding komen te staan met de beekloop, wat een positieve stimulans voor de biodiversiteit in het beekdal blijkt.

ii) enkele maanden na het suppleren van zand ontstaat er een veel gevarieerdere beekbodem, die bestaat uit een mozaïek van habitattypen en stroomsnelheden, waarvan voor dit beektype kenmerkende soorten profiteren.

Uit de monitoring van 2016 blijkt dat er nog steeds zandverplaatsingen optreden op de meetlocaties Z1, Z2 en Z3, ondanks dat de suppleties er een jaar geleden zijn gestaakt (Verdonschot et al., 2017). Om in beeld te krijgen of de zandverplaatsing op een gegeven moment stopt en een stabiel evenwicht ontstaat, is het belangrijk de veranderingen in de morfologie vast te blijven leggen. Daarom zijn in 2017 twee maal de bestaande dwarsprofieltransecten uit de eerdere onderzoeken ingemeten (1x voorjaar en $1 \times$ najaar).

Er zijn als gevolg van de ingrepen bijzondere nat-droog gradiënten ontstaan op een aantal van de suppletieplekken. Op dit moment zijn er twee typen aanwezig:

a. Overstromingszones (winterhalfjaar nat) met moerasvegetatie (best ontwikkeld rond Z1).

b. Zandbanken met spaarzame begroeiing (best ontwikkeld benedenstrooms Z4).

Beide habitats zijn karakteristiek voor natuurlijke laaglandbeken, maar in Nederland op dit moment zeer zeldzaam. Juist op deze plekken kan een karakteristieke flora en fauna worden 
aangetroffen van vaak zeer specialistische en kritische soorten. Voor het project geldt nu dat de ecologische (meer)waarde van deze ontwikkeling op dit moment onduidelijk is en ook ontbreekt een beeld van de ontwikkelingsrichting (naar open moeras, ruigte of beekbegeleidend bos ter vervanging van de afstervende bomen?). Om hier een beter beeld van te krijgen zijn op verschillende plekken vegetatieopnamen gemaakt en is daarnaast de semi-terrestrisch (oeverbewonende) ongewerveldenfauna bestudeerd.

Deze laatste groep wordt nog niet veel gebruikt in nederland om de effecten van beekherstel te meten. Echter, één van de belangrijkste conclusies van het internationale beek- en rivierherstel onderzoeksproject REFORM was dan ook dat succesvol beek- en rivierherstel afgeleid kon worden van de ontwikkelingen die zich in de beekbegeleidende zone afspelen (Hering et al., 2015). Met name de semi-terrestrische fauna blijkt indicatief voor hydrologische en morfologische ontwikkelingen langs beken en rivieren door hun sterke respons op vocht, sedimentsamenstelling, licht, vegetatiestructuur, trofie enzovoorts (Rainio \& Niemela, 2003; Lambeets et al., 2008, 2009; Januschke et al., 2011; Januschke \& Verdonschot, 2016). Net zoals voor macrofauna is er een groot aantal eigenschappen (milieu- en habitatpreferenties, 'traits') beschreven die in verband te brengen zijn met stressoren. Voordeel van deze semi-terrestrische groepen is dat, in tegenstelling tot veel macrofauna, de meeste soorten een goed dispersievermogen hebben, waardoor ze relatief snel kunnen opduiken op het moment dat de omstandigheden geschikt zijn.

De ontwikkelingen in de oeverzone zijn in 2017 vastgelegd, zodat deze later als referentiekader kunnen dienen voor de ontwikkelingen die de komende jaren plaats gaan vinden.

\section{Methode}

\subsection{Dwarsprofieltransectmetingen}

Om vast te stellen of er veranderingen zijn opgetreden in de bodemhoogte op de bestaande meetplekken (Z1, Z2, Z3; 27 dwarsprofieltransecten) ten opzichte van de situatie in 20142016, zijn in 2017 de bestaande transecten twee maal ingemeten (Figuur 1, 2). Meting 1 is uitgevoerd op 13 april 2017, volgend op een periode met langdurig relatief veel afvoer, waardoor hier de grootste verschillen worden verwacht. Meting 2 is uitgevoerd op 13 september 2017. Deze meting geeft de situatie weer na een periode met lage afvoeren (met af en toe een piekje na hevige buien). Deze tweede meting kan verschillen in bodemhoogte opleveren, maar biedt vooral een nulmeting van de situatie voordat de afvoer in het najaar weer structureel gaat stijgen en biedt dus goede vergelijkingsmogelijkheden met de voorjaarsmeting in het volgende jaar. Ter vergelijking zijn ook telkens de drie bovenstroomse dwarsprofieltransecten als controletrajecten gemonitord (Figuur 2). 


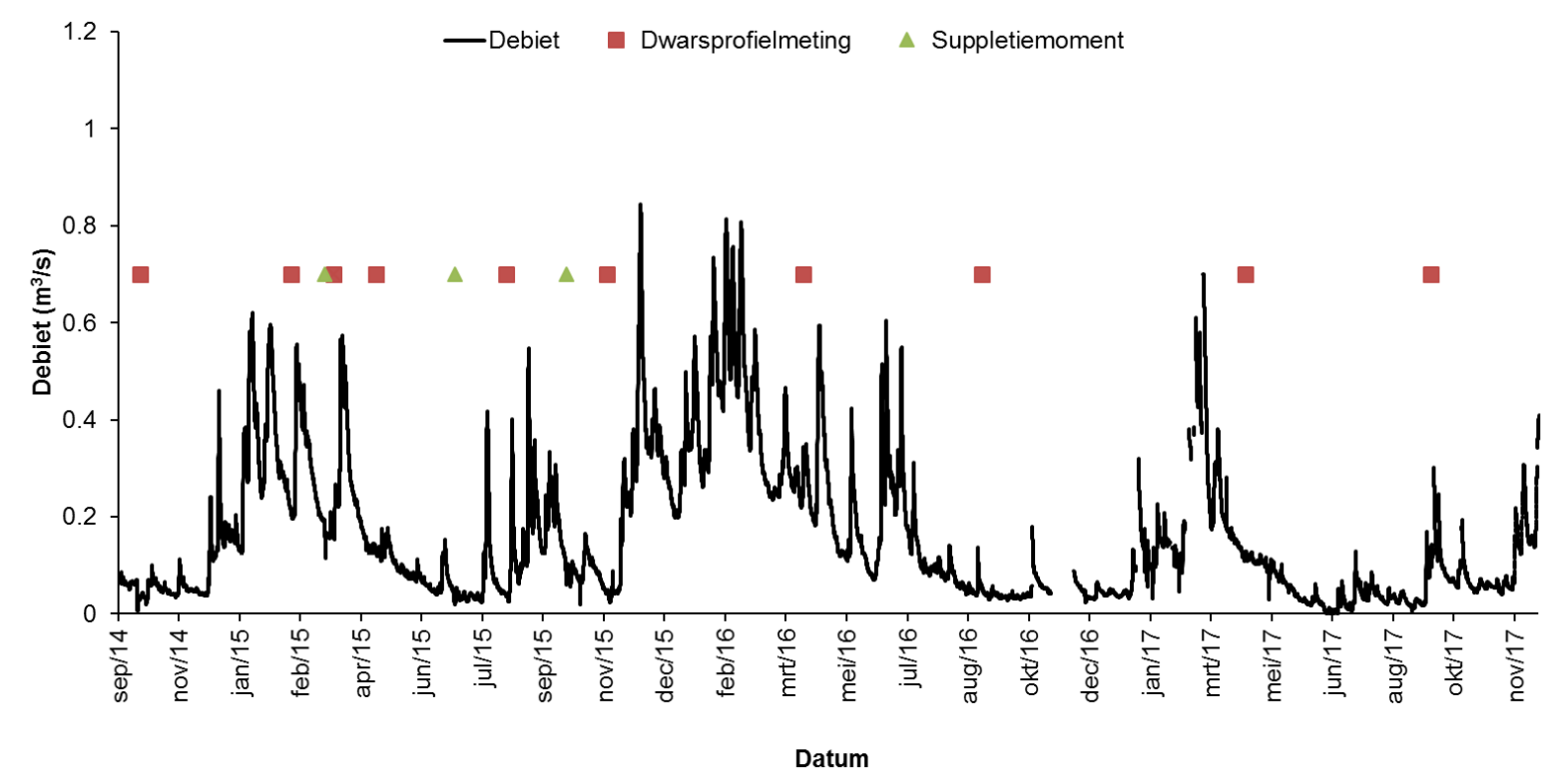

Figuur 1: De afvoer van de Hierdense beek in 2014-2017, gemeten op het debietmeetpunt ter hoogte van de A28, met duiding van de momenten waarop zand is gesuppleerd en wanneer de dwarsprofielmetingen zijn uitgevoerd.

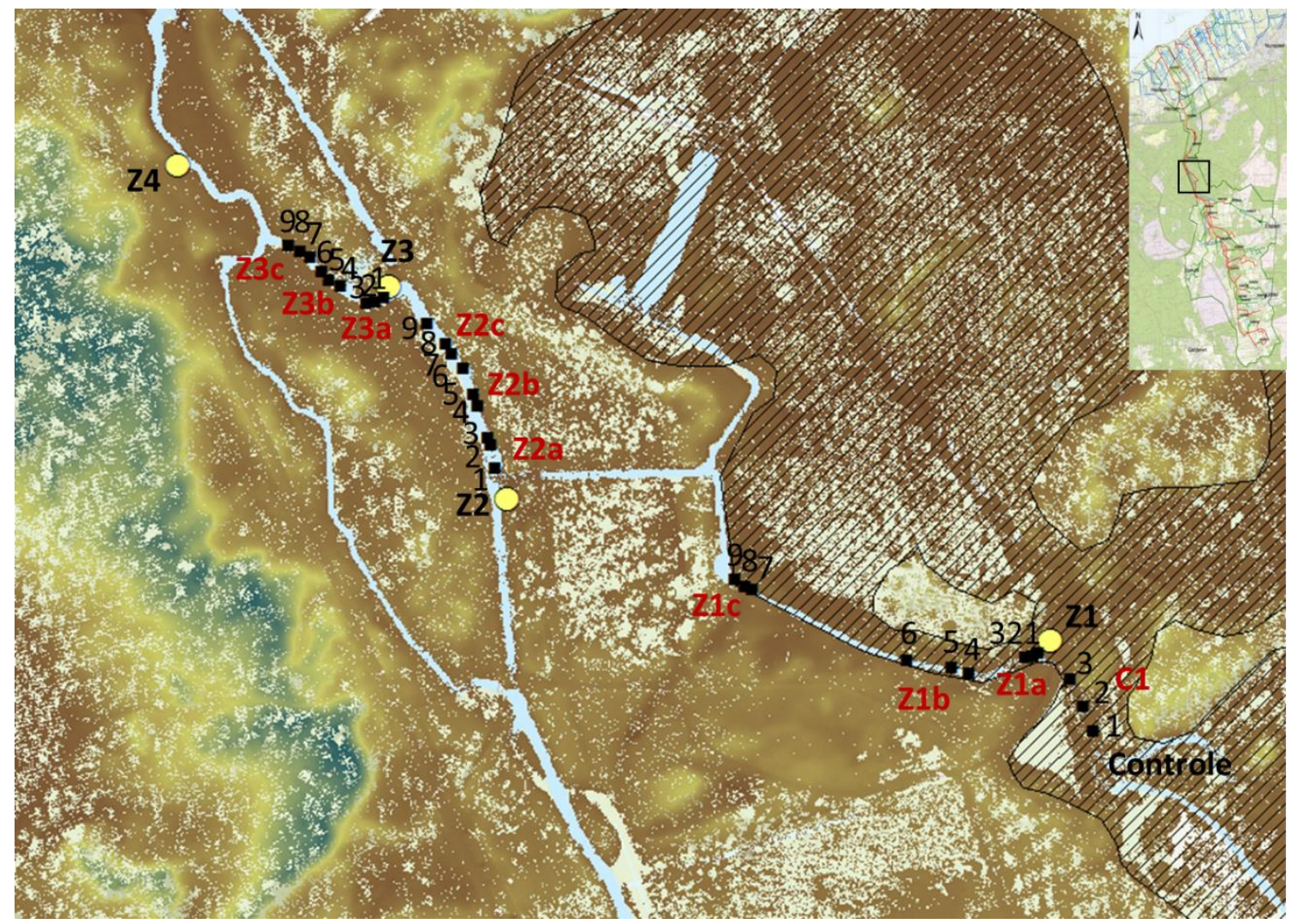

Figuur 2: Overzichtskaart studiegebied met de dwarsprofieltransecten waarin de bodemhoogteveranderingen zijn vastgelegd. Codes en nummers verwijzen naar de transecten (zie Bijlage 1). Gele cirkels geven suppletielocaties aan, gearceerde vlakken inundatiegebieden tijdens piekafvoeren. 


\subsection{Flora en fauna van de oeverzones}

Om de ontwikkeling van de oeverzone na zandsuppletie vast te leggen zijn 6 trajecten van 50 meter lengte onderzocht, plus 1 controletraject in het droge bos op enige afstand van de beek (Figuur 3). Deze trajecten hebben verschillende typen oevers. Er werd onderscheid gemaakt tussen:

1. Ingesneden gekanaliseerde beekoever met een harde natdroog overgang, de bovenstroomse gelegen uitgangsoftewel controlesituatie. Zwaar beschaduwd.

2. Vernatte beekoever als gevolg van de door zandsuppletie omhoog gekomen beekbedding, welke in de winter tijdens afvoerpieken geinundeerd is. Bossterfte door de vernatting zorgt voor open plekken in het bladerdak.

3. Beekmoeras, beek op maaiveld en permanent nat. Open, grootste gedeelte van het bos is afgestorven.

4. Zandbanken binnen de oorspronkelijke bedding. Ontstaan na zandsuppletie op plekken waar de beek voormalige stuifduinen doorsnijdt; beek kan hier geen overstromingsvlaktes vormen door diepe ligging. Zandbanken zijn alleen bij lage waterstanden droog.
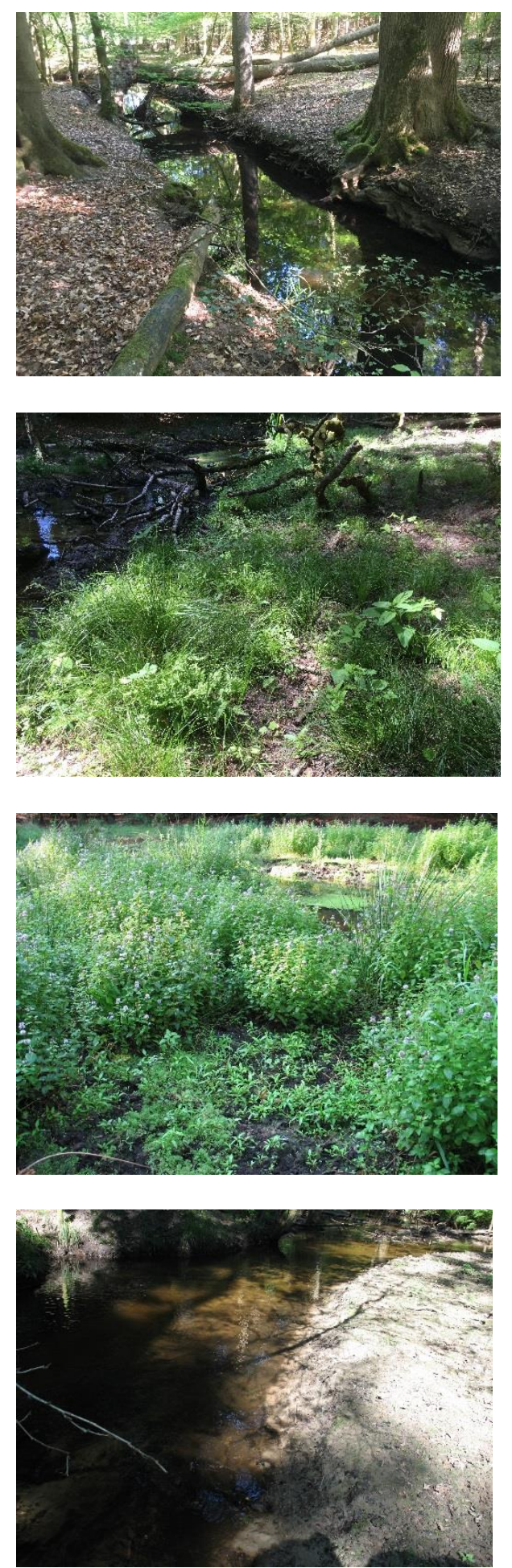
5. Controletraject in het droge bos op ongeveer $10 \mathrm{~m}$ van de beek. Dit dient als controlemeting om onderscheid te kunnen maken tussen de fauna van het bos en de fauna die leeft op de beekoevers.

Er zijn in de periode 19-6-2017 tot 26-6-2017 zowel vegetatieopnamen gemaakt als bemonsteringen uitgevoerd aan de semi-terrestrische fauna op de oevers.

Vegetatieopnamen zijn gemaakt van de beek (watervegetatie) en de beekbegeleidende zone (moerasvegetatie binnen het overstromingsbereik van de beek) volgens de recent ontwikkelde en op de huidige KRW methoden aansluitende doorstroommoerassen en moerasbeken systematiek (Verdonschot et al., 2016b). Deze opnamen geven aan welke plantensoorten (en zaailingen struiken en bomen) de plekken inmiddels hebben gekoloniseerd en geven een beeld van de ecologische kwaliteit en de ontwikkelingsrichting van de oeverzones.

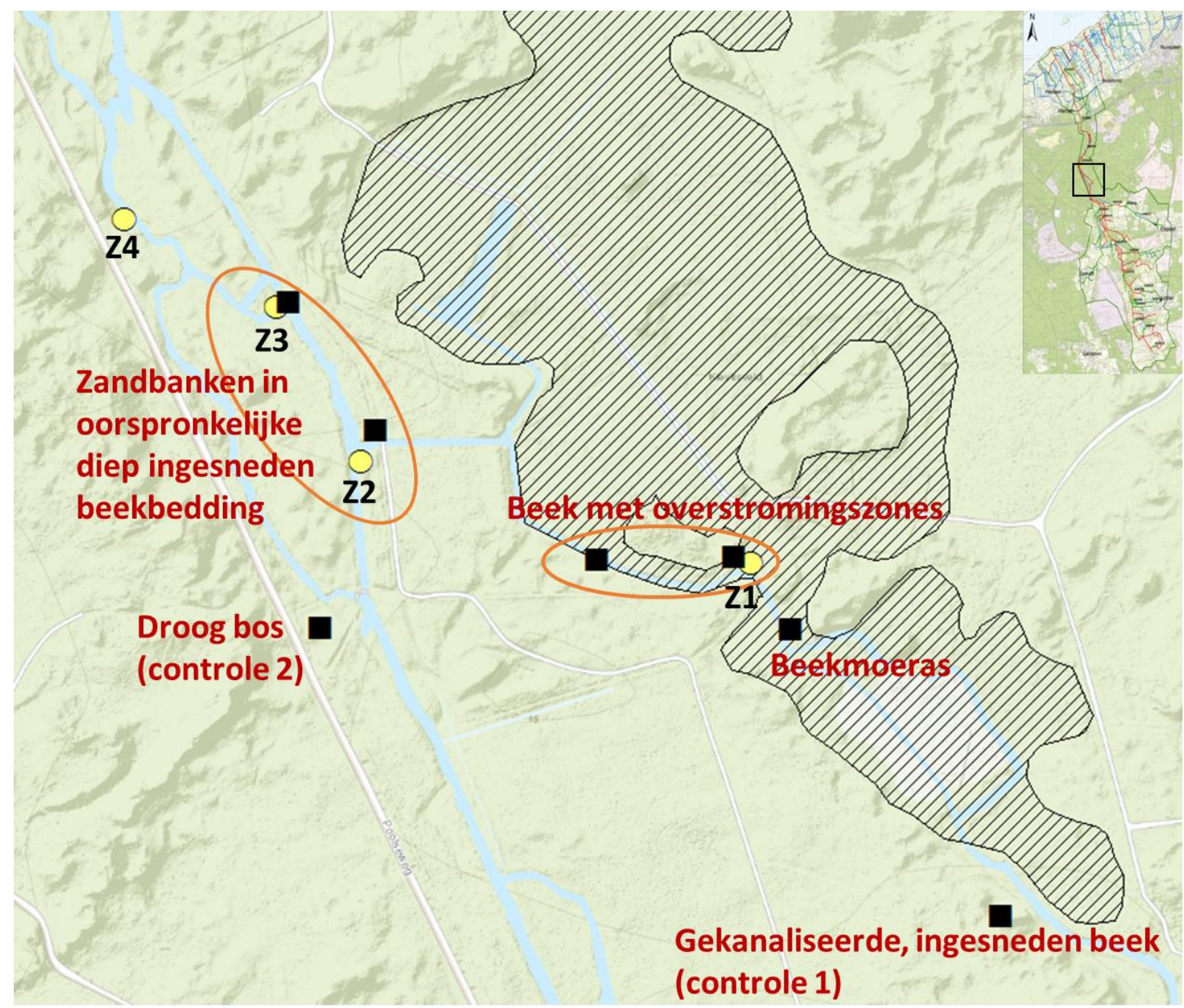

Figuur 3: Ligging van de 7 onderzoekslocaties langs de Leuvenumse beek. Zwarte vierkanten geven de ligging van de flora en faunameetpunten weer, gele cirkels de zandsuppletielocaties inclusief locatiecode (Z1 t/m Z4). Het gearceerde gedeelte inundeert bij piekafvoeren.

Rond de waterlijn zijn potvallen geplaatst om loopkevers en wolfspinnen te verzamelen. Per transect werden 10 vangpotten ingegraven. De potvallen hadden een diameter van $5 \mathrm{~cm}$ en een diepte van $10 \mathrm{~cm}$. Ze werden voorzien van een dakje tegen de regen en om te voorkomen dat muizen en kikkers in de vallen terecht konden komen (petrischaal met paar lange satéprikkers). Elke pot was gevuld met $100 \mathrm{ml}$ Renner-oplossing (40\% ethanol, 20\% 
glycerine, $10 \%$ azijnzuur, 30\% water en een scheutje afwasmiddel om de oppervlaktespanning te verlagen) voor de conservering van de gevangen dieren. $\mathrm{Na}$ een week werden de potten weer opgehaald en de inhoud gedetermineerd. Omdat vooral op zandbanken potvallen voor loopkevers niet altijd goed functioneren, zijn de potvalvangsten aangevuld met handvangsten. Hiervoor werden per transect 3 plots van $1 \times 1 \mathrm{~m}$ afgebakend (tegen de waterlijn aan), welke gedurende 10 minuten werden afgezocht op loopkevers. $\mathrm{Er}$ werd water over de plot gegoten om ook ingegraven dieren (deze komen dan naar boven) te kunnen verzamelen.

\section{Resultaten en discussie}

\subsection{Dwarsprofieltransectmetingen}

\section{Traject C1}

Het controletraject bovenstrooms van Z1 heeft zich ontwikkeld tot een moerasbeek met permanent natte oeverzones met veel moerasvegetatie (Figuur 4). De profielvorm wisselde van meting tot meting (Bijlage 1). De verschillen hangen mogelijk samen met enerzijds de vegetatieontwikkeling die zorgt voor slibinvang en het ontstaan van slibbanken langs de oevers en anderzijds de activiteiten van wilde zwijnen die zorgen dat plekken weer open worden gemaakt (zoelplekken) en het slib verdwijnt naar benedenstrooms.

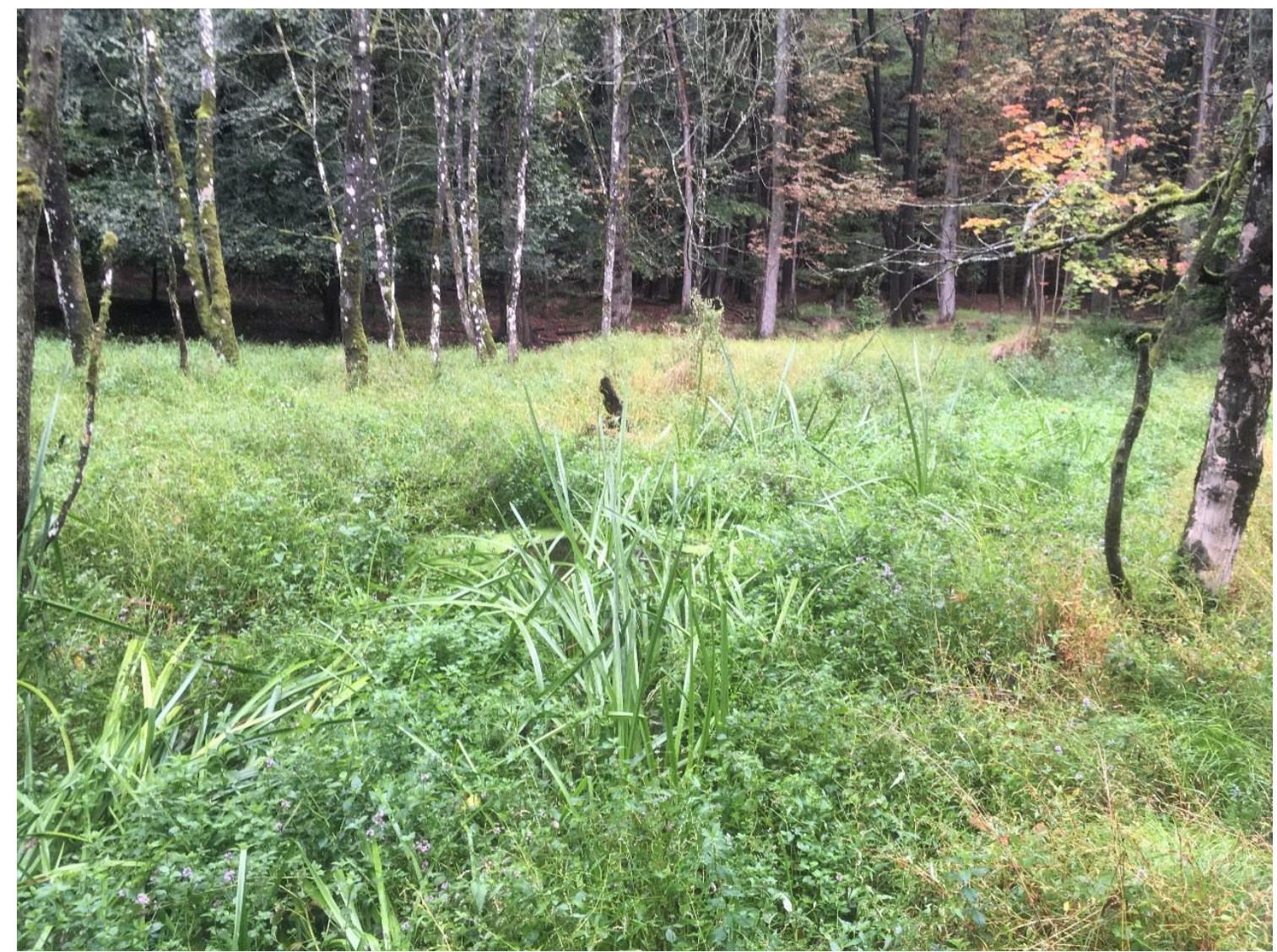

Figuur 4: Controletraject C (net bovenstrooms suppletielocatie Z1) in september 2017. Permanent nat en dicht begroeid met moerasvegetatie.

\section{Traject Z1}

Ten opzichte van de situatie in 2016 is er weinig veranderd; er lijkt zich een evenwichtsituatie in te stellen met lokaal nog kleine veranderingen in breedte en diepte (Bijlage 1). In het 
voorjaar was zand verplaatst (lokale ophoging), wat vervolgens in september weer verdwenen was (terug op niveau 2016; Figuur 5). De beek is ten opzichte van 2014 in zijn geheel opgehoogd tot en met dwarsprofieltransect Z16b. Een kleiner profiel heeft een aantal voor het beekecosysteem gunstige eigenschappen, zoals behoud van relatief hoge stroomsnelheid bij lage afvoer en het snel buiten de oevers treden van de beek bij hoge afvoer, waardoor een overstromingszone ontstaat. Dit laatste is op deze locatie duidelijk zichtbaar in de vegetatie (Figuur 6). In de beek zelf is een heterogeen mosaiek ontstaan van vooral vegetatie (Grote waterranonkel en Sterrenkroos) zand en grindbedden (Figuur 7).

\section{Locatie Z1}

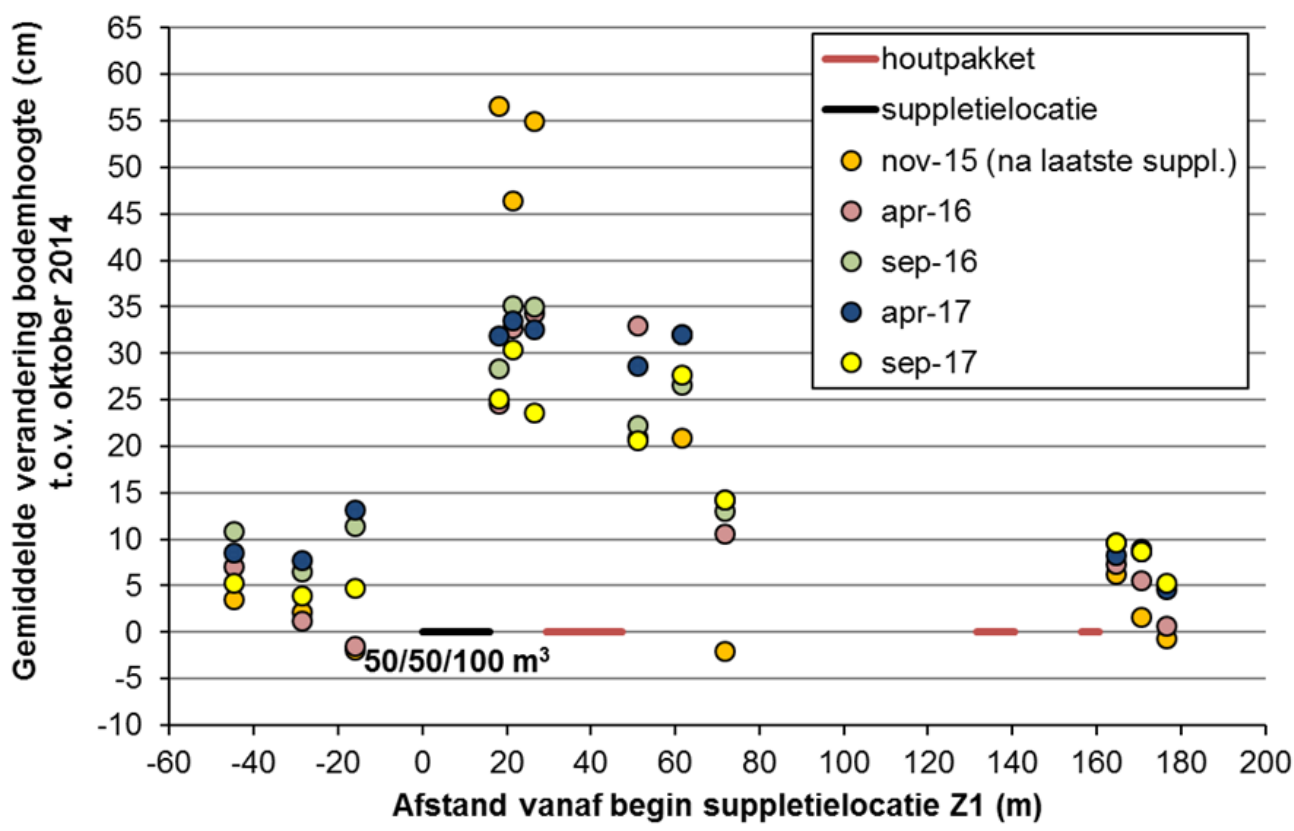

Locatie $\mathbf{Z 2 + Z 3}$

B

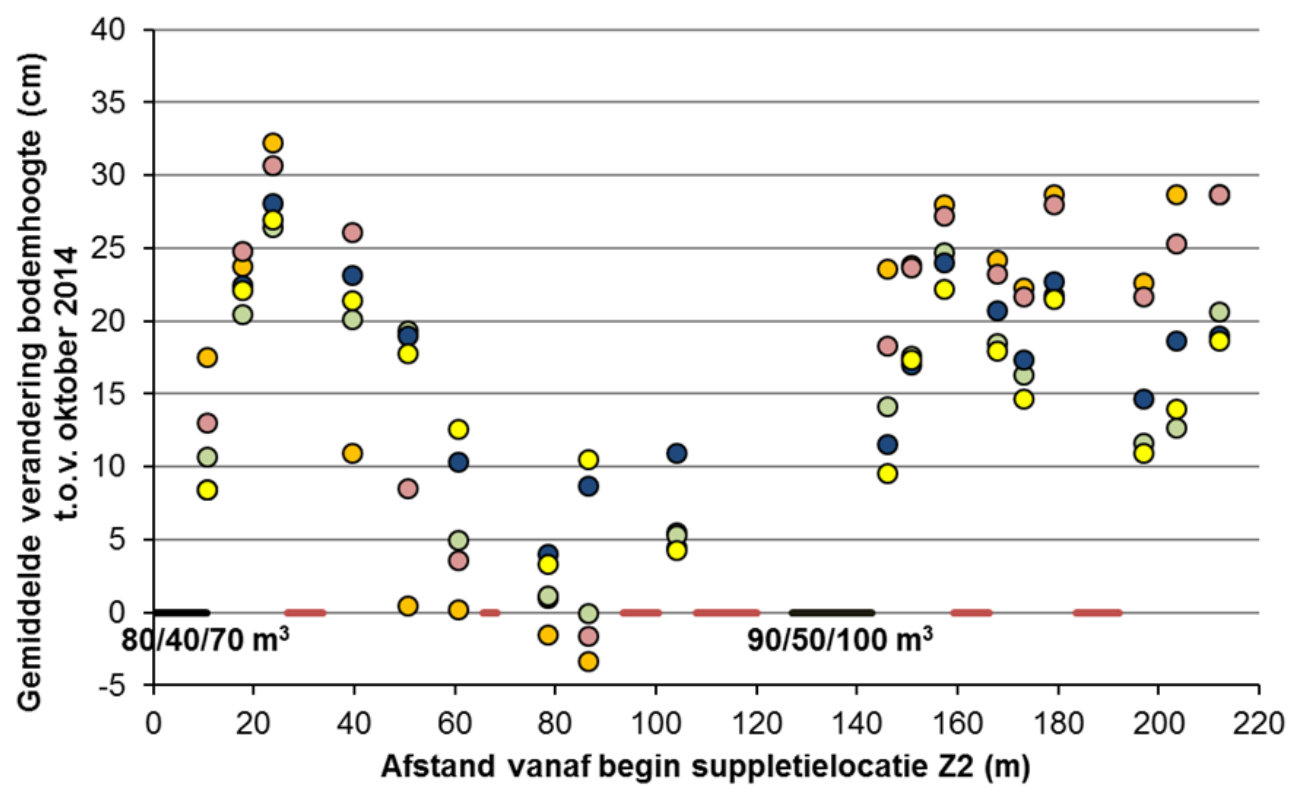

Figuur 5: Verandering van de gemiddelde bodemhoogte in de beektrajecten ten opzichte van de situatie in oktober 2014 (= nullijn). De laatste suppletie heeft plaatsgevonden in oktober 2015; de getallen onder de zwarte lijnen (positie suppletielocaties in het beektraject) geven een schatting van de totale hoeveelheid ingebracht zand per locatie. Het aantal meetpunten per dwarsprofiel bedroeg gemiddeld 3,3 in Z1, 7,2 in Z2 en 4,6 in Z3. 


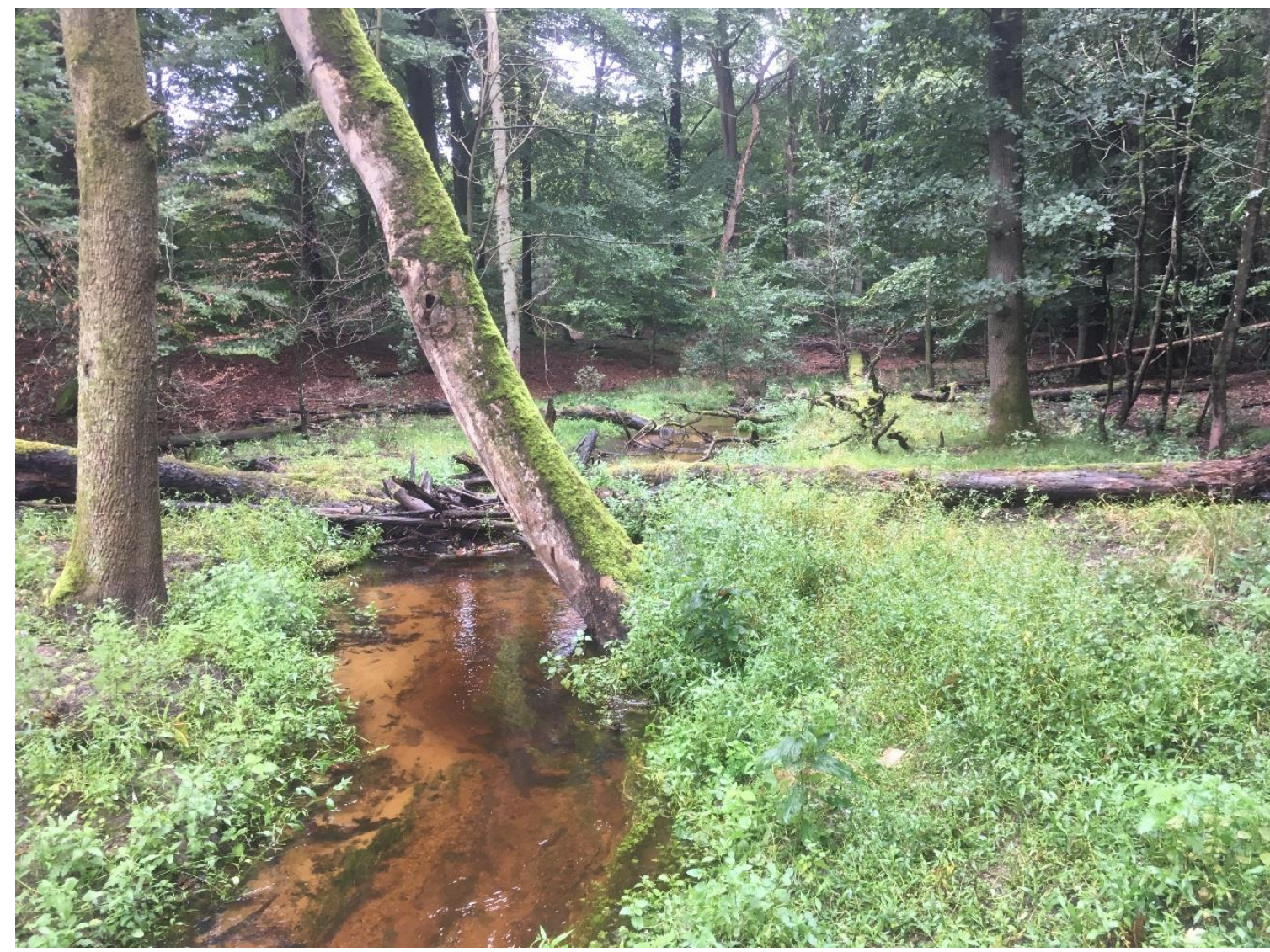

Figuur 6: Benedenstrooms zandsuppletielocatie Z1 september 2017: profiel in evenwicht ten opzichte van 2016, veel vegetatie in overstromingszones langs de beek.

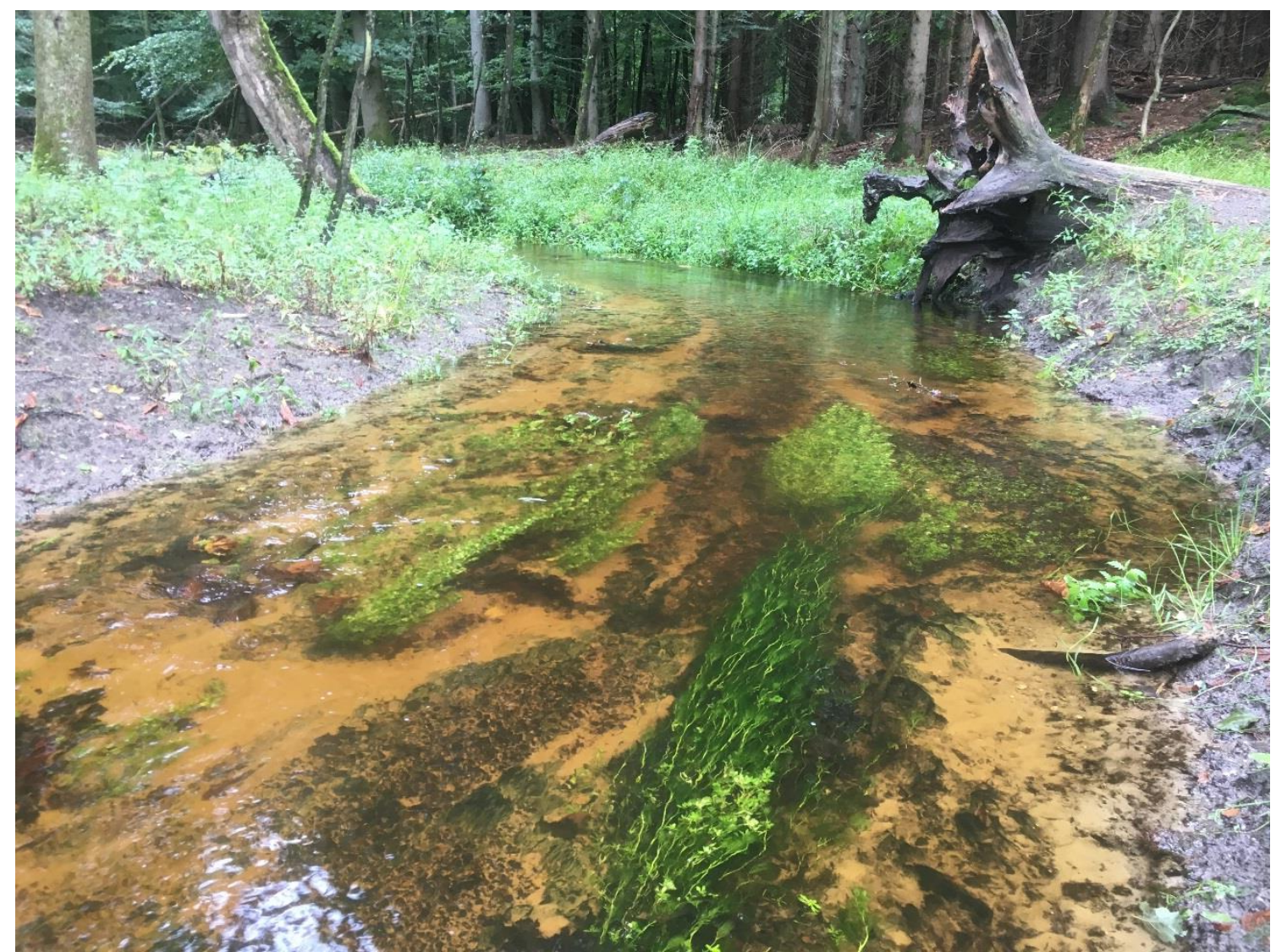

Figuur 7: Grindbedden op de plek (Z1) waar het zand oorspronkelijk is ingebracht. 


\section{Traject Z2}

In tegenstelling tot de stabiele situatie bij Z1 is de bodem benedenstrooms Z2 voor een deel nog volop dynamisch (Figuur 5). Tot Z2.5 is de situatie relatief stabiel en treedt vooral afvlakking op, vanaf Z2.5 is de bodem dynamisch met over het algemeen een bodemophoging (Bijlage 1, Figuur 8). Ter hoogte van Z2.8 was op 13 september een deel van een boomkruin in de beek gevallen (Figuur 9). Aangezien het hout voor veranderingen in erosie- en sedimentatieprocessen zorgt via veranderingen in stroomsnelheid, heeft dit consequenties voor de vervolgmetingen in dit transect en mogelijk ook benedenstrooms hiervan.

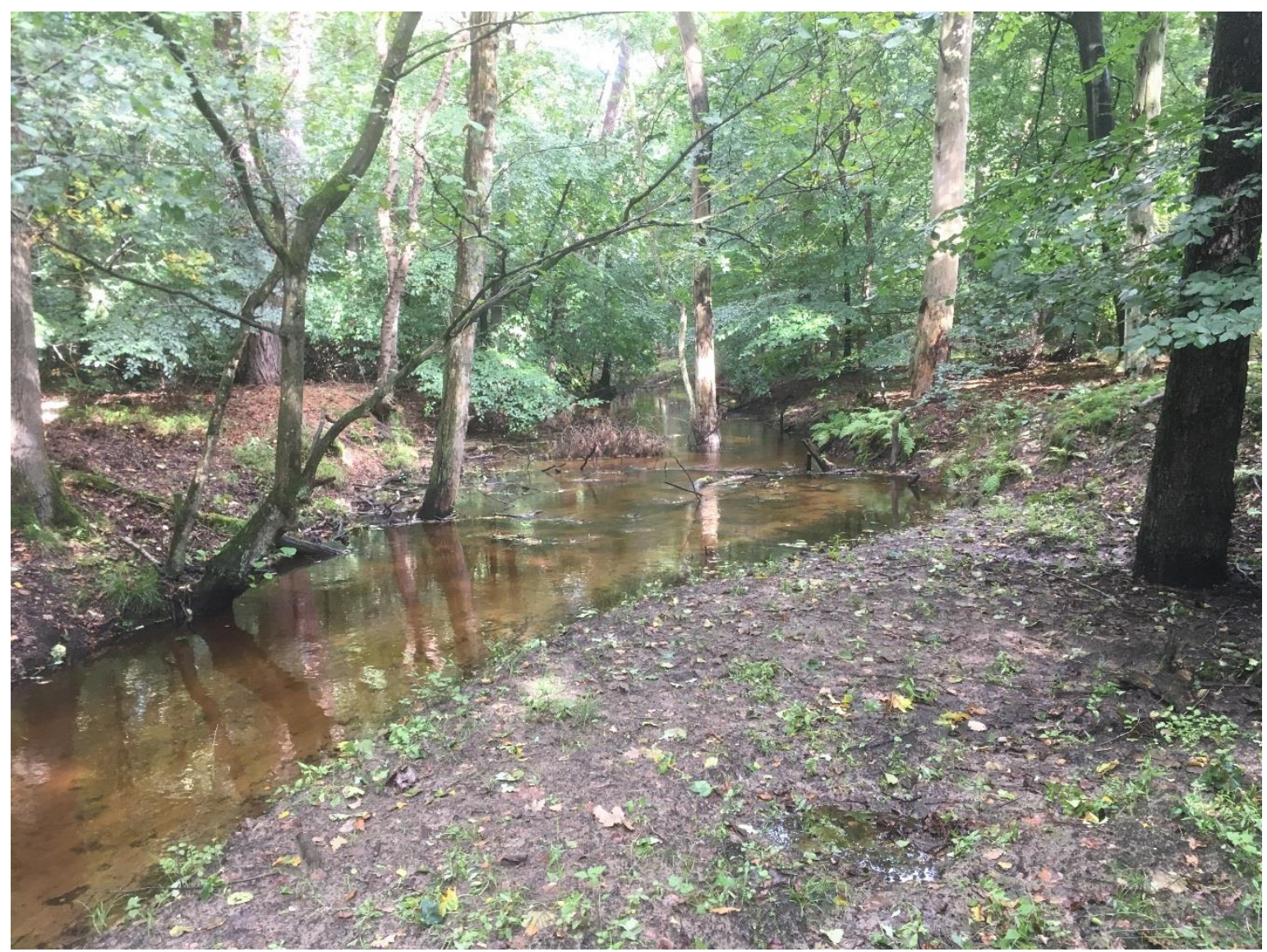

Figuur 8: Situatie benedenstrooms Z2 in september 2017. De beddingvorm van de eerste tientallen meters is weinig veranderd ten opzichte van 2016, vooral heeft afvlakking plaatsgevonden. Vegetatieontwikkeling op de zandbank geeft aan dat deze al langere tijd droog is en er weinig dynamiek is geweest.

\section{Traject $Z 3$}

In traject Z3 lijkt zich een evenwicht te hebben ingesteld, waarbij de beek in zijn geheel is opgehoogd (Figuur 10). Wel valt op dat er meer zandtransport is in de winterperiode (meer ophoging gemeten in het voorjaar), wat vervolgens in de zomerperiode weer afvlakt naar het niveau van de herfst ervoor (Bijlage 1). 


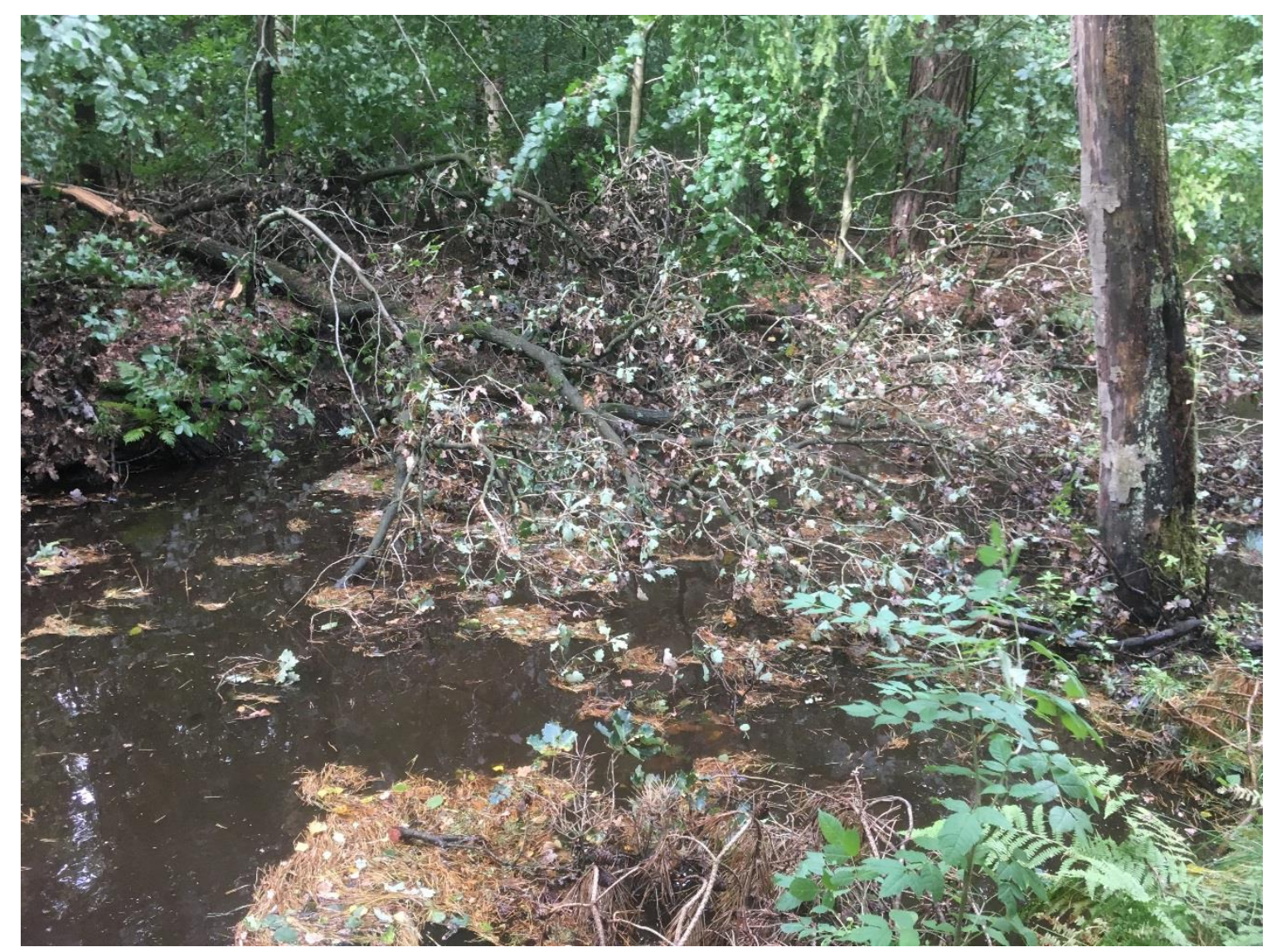

Figuur 9: Er is een deel van een boomkruin in transect Z2.8 terecht gekomen tijdens de storm van 13 september 2017.

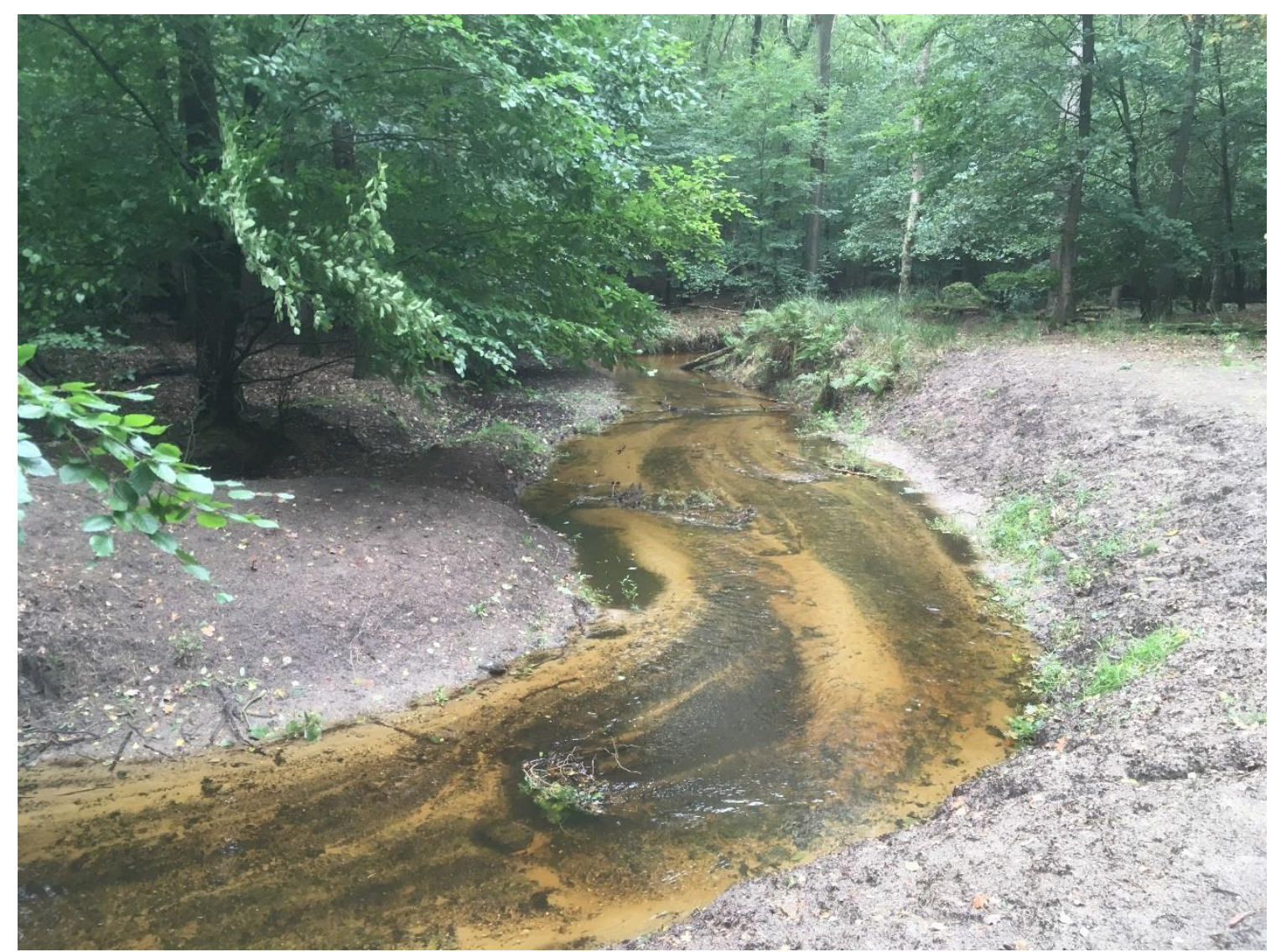

Figuur 10: Situatie ter hoogte van Z3 in september 2017. 


\subsection{Oever- en watervegetatie}

De transecten verschilden sterk in mate van beschaduwing en de hoeveelheid vegetatie op de oevers (Tabel 1). Het beekmoeras en de overstromingszones waren veel rijker aan plantensoorten dan het ingesneden gekanaliseerde traject (Tabel 2). Met name direct benedenstrooms Z1 was de diversiteit aan plantensoorten hoog en werden maar liefst 49 soorten aangetroffen, tegen slechts 13 soorten in de gekanaliseerde controle. Een groot deel van de soorten is gebonden aan natte tot vochtige omstandigheden en daarnaast aan voedselrijke situaties en plekken met bodemverstoring. Alle soorten zijn ook aangetroffen tijdens de vegetatiekartering van de Leuvenumse bossen in 2014 (te Linde et al., 2015). Dit geeft aan dat het uitbreiding van lokale populaties betreft en niet kolonisatie of het verschijnen van soorten uit een eventuele zaadbank.

Zaailingen van beekbegeleidende boomsoorten waren schaars op de oevers en meestal beperkt tot enkele exemplaren. Een klein aantal zaailingen van de Fladderiep werd aangetroffen in het beekmoeras en de overstromingszone na Z1. Op deze tweede locatie waren ook zaailingen van de Grauwe/geoorde/boswilg (te klein om soort te bepalen) aanwezig. In tegenstelling tot bijvoorbeeld de Fladderiep waren er geen volwassen wilgenbomen aanwezig in de transecten (Tabel 3). De Zwarte els, karakteristiek voor natte plekken langs laaglandbeken, werd niet aangetroffen in de transecten.

Een groot deel van de massaal opgekomen moerasplanten (bijv. Watermunt, Slanke Waterkers) in het beekmoeras en de overstromingszones zijn belangrijke nectarbronnen voor bloembezoekende insecten (o.a. vlinders, bijen, zweefvliegen). Het is dan ook de verwachting dat deze soorten profiteren van de toename aan moerasvegetatie op de open plekken langs de beek. 
Tabel 1: Ligging en eigenschappen 50-m-transecten op 19 juni 2017.

\begin{tabular}{|c|c|c|c|c|c|c|c|}
\hline Locatie & $\begin{array}{l}\text { gekanaliseerd } \\
\text { ingesneden traject }\end{array}$ & $\begin{array}{l}\text { beekmoeras en } \\
\text { overstromingsvlakte } \\
\text { bovenstrooms Z1 }\end{array}$ & $\begin{array}{l}\text { vernatte } \\
\text { oeverzone } \\
\text { Z1 }\end{array}$ & $\begin{array}{l}\text { vernatte zone door } \\
\text { uitstroom bij houtpakket }\end{array}$ & $\begin{array}{l}\text { zandbank } \\
\text { en bij Z3 }\end{array}$ & $\begin{array}{l}\text { zandbank } \\
\text { en bij Z2 }\end{array}$ & $\begin{array}{l}\text { droog bos } 10 \\
\mathrm{~m} \text { van beek }\end{array}$ \\
\hline Afkorting & $\mathrm{IK}$ & $\mathrm{BM}$ & OV1 & Ov2 & ZB1 & ZB2 & $\mathrm{DB}$ \\
\hline $\begin{array}{l}\text { begin transect (x;y } \\
\text { coordinaten) }\end{array}$ & $\begin{array}{l}177300 ; \\
480884\end{array}$ & $\begin{array}{l}177140 \\
481102\end{array}$ & $\begin{array}{l}177096 ; \\
481157\end{array}$ & $\begin{array}{l}176991 ; \\
481155\end{array}$ & $\begin{array}{l}176755 \\
481351\end{array}$ & $\begin{array}{l}176822 \\
481253\end{array}$ & $\begin{array}{l}17678 ; \\
481103\end{array}$ \\
\hline $\begin{array}{l}\text { eind transect (x;y } \\
\text { coordinaten) }\end{array}$ & $\begin{array}{l}177305 \\
480911\end{array}$ & $\begin{array}{l}177117 \\
481123\end{array}$ & $\begin{array}{l}177079 \\
481136\end{array}$ & $\begin{array}{l}\text { 176966; } \\
481176\end{array}$ & $\begin{array}{l}176726 \\
481351\end{array}$ & $\begin{array}{l}176804 \\
481267\end{array}$ & $\begin{array}{l}176749 \\
481131\end{array}$ \\
\hline \multicolumn{8}{|c|}{ Eigenschappen oever } \\
\hline $\begin{array}{l}\text { Geslotenheid } \\
\text { bladerdak (\%) }\end{array}$ & 95 & 10 & 50 & 50 & 70 & 60 & 95 \\
\hline $\begin{array}{l}\text { Onbegroeide } \\
\text { bodem }(\%)\end{array}$ & 99 & 5 & 40 & 50 & 99 & 99 & 99 \\
\hline \multicolumn{8}{|c|}{ Eigenschappen beek } \\
\hline beek breedte $(\mathrm{m})$ & 3 & 3 & 3 & 3 & 1,5 & 2 & n.v.t. \\
\hline beek diepte $(\mathrm{m})$ & 0,2 & 0,4 & 0,1 & 0,2 & 0,15 & 0,1 & n.v.t. \\
\hline hoogte kant (m) & 1,2 & 0 & 0,3 & 0,3 & 0 & 0 & n.v.t. \\
\hline Grind (\%) & 0 & 0 & 5 & 0 & 20 & 30 & n.v.t. \\
\hline Zand (\%) & 10 & 40 & 50 & 30 & 65 & 30 & n.v.t. \\
\hline FPOM $^{*}(\%)$ & 75 & 35 & 10 & 30 & 5 & 30 & n.v.t. \\
\hline $\mathrm{CPOM}^{* *}(\%)$ & 10 & 20 & 5 & 30 & 5 & 5 & n.v.t. \\
\hline Dood hout (\%) & 5 & 5 & 30 & 10 & 5 & 5 & n.v.t. \\
\hline $\begin{array}{l}\text { Emerse vegetatie } \\
(\%)\end{array}$ & 0 & 25 & 0 & 0 & 0 & 0 & n.v.t. \\
\hline $\begin{array}{l}\text { Submerse } \\
\text { vegetatie (\%) }\end{array}$ & 0 & 50 & 1 & 0 & 0 & 0 & n.v.t. \\
\hline Draadalg (\%) & 0 & 0 & 0 & 0 & 30 & 30 & n.v.t. \\
\hline
\end{tabular}

${ }^{\star} \mathrm{FPOM}$ = fijn organisch materiaal deeltjes, ${ }^{\star \star} \mathrm{CPOM}$ : grof organisch materiaal deeltjes (bladfragmenten, takjes, beukenootjes) 
Tabel 2: Samenstelling kruidlaag transecten water en oeverzone in juni 2017, inclusief zaailingen van boomsoorten. Bedekking is weergegeven volgens de Tansley-schaal: $r$ : 1-4 exemplaren $<5 \%$ bedekking, o: 5-10 exemplaren $<5 \%$ bedekking, $f: 1-10$ exemplaren per $m^{2}$ $<5 \%$ bedekking, la 5-12\% transectoppervlakte, a: 13-25\%, ld: 26-50\%, cd: 50-75\%, d: $75-$ $100 \%$. Ook de watervegetatie is opgenomen. Moeras en waterplanten zijn weergegeven in vet. IK: ingesneden, gekanaliseerd; BM: beekmoeras, OV: overstromingszones, ZB:

zandbanken, DB: droog bos (zie Tabel 1).

\begin{tabular}{|c|c|c|c|c|c|c|c|c|}
\hline \multirow[t]{2}{*}{ Soort } & \multirow[t]{2}{*}{ Nederlandse naam } & \multicolumn{7}{|c|}{$\begin{array}{l}\text { Relatieve bedekking transect (Tansley- } \\
\text { schaal) }\end{array}$} \\
\hline & & IK & BM & OV1 & OV2 & ZB1 & ZB2 & DB \\
\hline Fagus sylvatica & Beuk & 0 & & 0 & 0 & & 0 & 0 \\
\hline Fraxinus excelsior & Es & 0 & & & & & & \\
\hline Ilex aquifolium & Hulst & $r$ & & & & & & \\
\hline Acer pseudoplatanus & Gewone esdoorn & $r$ & & $r$ & 0 & & & \\
\hline Ulmus laevis & Fladderiep & & 0 & $\mathbf{r}$ & & & & \\
\hline Quercus robur & Zomereik & & & $r$ & 0 & & & \\
\hline Salix caprea/aurita/cinerea & Wilg & & & 0 & & & & \\
\hline Pinus sylvestris & Grove den & & & & & $r$ & 0 & \\
\hline Prunus serotina & Amerikaanse vogelkers & & & & & & & $r$ \\
\hline Vaccinium myrtillus & Blauwe bosbes & & & & & & & 0 \\
\hline Dryopteris sp. & Stekelvaren & 0 & & 0 & 0 & & & \\
\hline Dryopteris dilatata & Brede stekelvaren & & & & & & 0 & 0 \\
\hline Athyrium filix-femina & Wijfjesvaren & & & $r$ & & $r$ & 0 & \\
\hline Polypodium vulgare & Gewone eikvaren & $r$ & & & & & & \\
\hline Deschampsia cespitosa & Ruwe smele & & 0 & $f$ & $f$ & & & \\
\hline Poa nemoralis & Bosbeemdgras & $r$ & & & & & & \\
\hline Poa trivialis & Ruw beemdgras & & 0 & 0 & 0 & 0 & & \\
\hline Agrostis stolonifera & Fioringras & & $a$ & $f$ & la & 0 & 0 & \\
\hline Carex remota & IJle zegge & 0 & r & $\mathrm{a}$ & $f$ & & 0 & \\
\hline Dactylis glomerata & Kropaar & $r$ & & & & & & \\
\hline Holcus lanatus & Gestreepte witbol & & & $r$ & & & 0 & \\
\hline Phalaris arundinacea & Rietgras & & & & & & $r$ & \\
\hline Juncus effusus & Pitrus & & $r$ & $r$ & & & & \\
\hline Juncus bufonius & Greppelrus & & 0 & & & 0 & & \\
\hline Luzula multiflora & Veelbloemige veldbies & & & $r$ & & & & \\
\hline Stellaria uliginosa & Moerasmuur & 0 & $r$ & 0 & la & 0 & $r$ & \\
\hline Stellaria media & Vogelmuur & & $f$ & & $f$ & & & \\
\hline Urtica dioica & Grote brandnetel & 0 & $r$ & 0 & 0 & $r$ & & \\
\hline Cardamine flexuosa & Bosveldkers & 0 & 0 & 0 & 0 & 0 & 0 & \\
\hline Nasturtium microphyllum & Slanke waterkers & & $f$ & $r$ & & & & \\
\hline Rorippa palustris & Moeraskers & & 0 & $r$ & & & & \\
\hline Capsella bursa-pastoris & Herderstasje & & & $r$ & & & & \\
\hline Ceratocapnos claviculata & Rankende helmbloem & $r$ & & & & $r$ & $r$ & \\
\hline Mentha aquatica & Watermunt & & la & la & 0 & & & \\
\hline Mentha arvensis & Akkermunt & & & 0 & & & & \\
\hline Lycopus europaeus & Wolfspoot & & 0 & 0 & 0 & $r$ & 0 & \\
\hline
\end{tabular}




\begin{tabular}{|c|c|c|c|c|c|c|c|c|}
\hline \multirow[t]{2}{*}{ Soort } & \multirow[t]{2}{*}{ Nederlandse naam } & \multicolumn{7}{|c|}{$\begin{array}{l}\text { Relatieve bedekking transect (Tansley- } \\
\text { schaal) }\end{array}$} \\
\hline & & IK & BM & OV1 & OV2 & ZB1 & ZB2 & DB \\
\hline Myosotis scorpioides & Moerasvergeetmijnietje & & la & 0 & 0 & $r$ & & \\
\hline Myosotis laxa & Zompvergeetmijnietje & & 0 & & 0 & & & \\
\hline Persicaria hydropiper & Waterpeper & & $\mathrm{a}$ & $f$ & $\mathrm{a}$ & 0 & 0 & \\
\hline Sparganium erectum & Grote egelskop & & $f$ & & & & & \\
\hline Lemna minor & Klein kroos & & 0 & & & & 0 & \\
\hline Bidens frontosa & Zwart tandzaad & & 0 & 0 & 0 & & $r$ & \\
\hline Galium aparine & Kleefkruid & & $r$ & 0 & $r$ & & & \\
\hline Galium palustre & Moeraswalstro & & $r$ & 0 & $r$ & & $r$ & \\
\hline Glechoma hederacea & Hondsdraf & & 0 & 0 & 0 & $r$ & & \\
\hline Lysimachia nummularia & Penningkruid & & $r$ & 0 & 0 & $r$ & & \\
\hline Rumex conglomeratus & Kluwenzuring & & $r$ & $r$ & & & & \\
\hline Rumex acetosella & Schapenzuring & & & & & & $r$ & \\
\hline Ranunculus peltatus & Grote waterranonkel & & $f$ & $r$ & & & & \\
\hline Ranunculus scleratus & $\begin{array}{l}\text { Blaartrekkende } \\
\text { boterbloem }\end{array}$ & & $r$ & $r$ & 0 & $r$ & $r$ & \\
\hline Ranunculus repens & Kruipende boterbloem & & & 0 & $r$ & & & \\
\hline Hypericum perforatum & Sint-Janskruid & & $r$ & & 0 & & & \\
\hline Fallopia convolvulus & Zwaluwtong & & 0 & 0 & & & & \\
\hline Berula erecta & Kleine watereppe & & $f$ & 0 & & & & \\
\hline Callitriche obtusangula & Stomphoekig sterrekroos & & la & 0 & & & & \\
\hline Callitriche sp. & Sterrekroos & & 0 & & & & $r$ & \\
\hline Oxalis stricta & Stijve klaverzuring & & $r$ & 0 & 0 & $r$ & $r$ & \\
\hline Eupatorium cannabinum & Koninginnenkruid & & $r$ & $r$ & 0 & & & \\
\hline Iris pseudacorus & Gele lis & & $r$ & $r$ & & & & \\
\hline Scrophularia nodosa & Knopig helmkruid & & & 0 & $r$ & & & \\
\hline Impatiens parviflora & Klein springzaad & & & 0 & 0 & $r$ & & \\
\hline Scutellaria galericulata & Blauw glidkruid & & & $f$ & $r$ & & & \\
\hline Lamium album & Witte dovenetel & & & $r$ & & & & \\
\hline Valeriana officinalis & Echte valeriaan & & & $r$ & & & & \\
\hline Filipendula ulmaria & Moerasspirea & & & $r$ & & & & \\
\hline Ajuga reptans & Kruipend zenegroen & & & 0 & 0 & & & \\
\hline Viola riviniana & Bleeksporig bosviooltje & & & $r$ & 0 & & & \\
\hline Gnaphalium uliginosum & Moerasdroogbloem & & 0 & & 0 & $r$ & & \\
\hline Rubus & Braam & & & & & & $r$ & \\
\hline Galeopsis & Hennepnetel & & & $r$ & & & & \\
\hline Bryophyta & Bladmossen & $f$ & 0 & 0 & 0 & 0 & $r$ & \\
\hline Totaal aantal taxa (excl. b & nossen) & 13 & 37 & 49 & 33 & 18 & 21 & 4 \\
\hline
\end{tabular}


Tabel 3: Samenstelling boomlaag boven water en oeverzone transecten in juni 2017. IK: ingesneden, gekanaliseerd; BM: beekmoeras, OV: overstromingszones, ZB: zandbanken, DB: droog bos (zie Tabel 1).

\begin{tabular}{|c|c|c|c|c|c|c|c|c|}
\hline \multirow[t]{2}{*}{ Transect } & & \multicolumn{7}{|c|}{$\begin{array}{l}\text { Relatieve samenstelling boomlaag per soort } \\
(\%)\end{array}$} \\
\hline & & IK & BM & OV1 & OV2 & ZB1 & ZB2 & DB \\
\hline Fagus sylvatica & Beuk & 50 & & 20 & & 25 & 60 & 60 \\
\hline Fraxinus excelsior & Es & 15 & & & & & & \\
\hline Ulmus laevis & Fladderiep & 25 & 50 & & & & & \\
\hline Quercus robur & Zomereik & 10 & 50 & 40 & 75 & 75 & 30 & 30 \\
\hline Acer pseudoplatanus & Gewone esdoorn & & & 40 & 25 & & & \\
\hline Pinus sylvestris & Grove den & & & & & & 10 & 5 \\
\hline Betula pubescens & Zachte berk & & & & & & & 5 \\
\hline
\end{tabular}

\subsection{Semi-terrestrische fauna: loopkevers en spinnen}

\section{Loopkevers}

In totaal zijn 41 soorten loopkevers aangetroffen (432 individuen). Hiervan waren 8 soorten (55 individuen) gebonden aan oevers. Deze groep omvat de echte watergebonden soorten, de semi-terrestrische specialisten. Echter, geen van deze soorten was een typische beeksoort; het waren soorten met een minder specifieke habitatbinding die zowel langs stilstaande als langzaam stromende wateren te vinden zijn. Verder waren 11 soorten gebonden aan vochtige terreinen in het algemeen (eurytoop). Wanneer de habitatvoorkeur tussen de verschillende trajecten vergeleken wordt, dan komt duidelijk naar voren dat de oevers met overstromingszones en het beekmoeras een duidelijke vochtminnende levensgemeenschap bevatten, terwijl dit voor het ingesneden gekanaliseerde traject, maar ook de zandbanken in de beek niet geldt (Figuur 11). Hier domineren bossoorten en soorten van droge terreinen. De consequentie van de omvorming van ingesneden gekanaliseerde trajecten naar overstromingszones en beekmoerassen heeft geleid tot een verhoging van de totale biodiversiteit van het bos. De bijdrage aan de totale biodiversiteit is geanalyseerd aan de hand van de alfa-, beta- en gammadiversiteit. Alfa-diversiteit is het aantal soorten op een locatie, beta diversiteit het aantal unieke soorten per locatie (dus niet voorkomend op de andere locatie) wanneer twee verschillende locaties vergeleken worden en gamma-diversiteit het totaal aantal soorten van alle locaties samen. Het blijkt dat ieder type oever zijn eigen soorten heeft, wat leidt tot een hoge totale soortenrijkdom (Figuur 12). Wordt er echter puur gekeken naar de specialisten, dan is het beekmoeras het enige type oever dat tot een relatief grote verhoging van de totale soortenrijkdom leidt.

\section{Wolfsspinnen}

In totaal zijn 7 soorten wolfsspinnen aangetroffen (177 individuen; Tabel 5). Vrijwel alle transecten waren soortenarm (slechts 1 soort), met uitzondering van het beekmoeras waar alle 7 soorten werden gevonden. Hiervan waren 4 soorten gebonden aan oevers. In transect OV1 (overstromingszone na Z1) werden 3 soorten gevonden, waarvan 2 gebonden aan oevers. 
Tabel 4: Samenstelling loopkeverfauna oeverzone in juni 2017.

\begin{tabular}{|c|c|c|c|c|c|c|c|c|}
\hline \multirow[t]{2}{*}{ Soort } & \multicolumn{7}{|c|}{ Transect } & \multirow[t]{2}{*}{ Habitat } \\
\hline & IK & BM & OV1 & OV2 & ZB1 & ZB2 & DB & \\
\hline Abax parallelepidus & 1 & 0 & 0 & 0 & 1 & 0 & 10 & bossen \\
\hline Carabus problematicus & 1 & 0 & 0 & 0 & 0 & 1 & 2 & bossen \\
\hline $\begin{array}{l}\text { Carabus violaceus } \\
\text { purpurascens }\end{array}$ & 0 & 0 & 0 & 0 & 1 & 0 & 1 & bossen \\
\hline Asaphidion curtum & 1 & 0 & 8 & 3 & 0 & 1 & 0 & bossen \\
\hline Pterostichus niger & 0 & 4 & 3 & 0 & 0 & 0 & 0 & bossen \\
\hline $\begin{array}{l}\text { Pterostichus } \\
\text { oblongopunctatus }\end{array}$ & 2 & 0 & 1 & 0 & 0 & 0 & 6 & bossen \\
\hline Limnodromus assimilis & 17 & 2 & 4 & 10 & 16 & 28 & 0 & bossen \\
\hline Notiophilus biguttatus & 0 & 0 & 1 & 0 & 1 & 0 & 0 & bossen \\
\hline Notiophilus rufipes & 0 & 0 & 1 & 0 & 0 & 0 & 1 & bossen \\
\hline Leistus rufimarginatus & 0 & 0 & 0 & 0 & 0 & 0 & 1 & bossen \\
\hline Abax parallelus & 2 & 0 & 0 & 0 & 0 & 0 & 7 & bossen \\
\hline Cychrus caraboides & 1 & 0 & 1 & 0 & 0 & 0 & 0 & bossen \\
\hline Bembidion lampros & 0 & 0 & 1 & 1 & 2 & 1 & 0 & droog \\
\hline Bembidion tetracolum & 1 & 1 & 5 & 5 & 6 & 3 & 0 & droog \\
\hline $\begin{array}{l}\text { Pterostichus } \\
\text { melanarius }\end{array}$ & 1 & 2 & 0 & 1 & 0 & 0 & 1 & droog \\
\hline Pterostichus strenuus & 0 & 0 & 0 & 1 & 0 & 0 & 0 & droog \\
\hline Nebria brevicollis & 5 & 0 & 2 & 1 & 1 & 0 & 0 & droog \\
\hline Trechus obtusus & 0 & 0 & 0 & 1 & 0 & 0 & 0 & droog \\
\hline Harpalus latus & 0 & 0 & 1 & 1 & 0 & 0 & 1 & droog \\
\hline Harpalus rufipes & 0 & 0 & 0 & 6 & 0 & 0 & 0 & droog \\
\hline Notiophilus substriatus & 0 & 0 & 0 & 0 & 1 & 1 & 0 & droog \\
\hline Paranchus albipes & 1 & 0 & 5 & 1 & 2 & 1 & 0 & oevers \\
\hline Agonum viduum & 1 & 25 & 1 & 0 & 0 & 1 & 0 & oevers \\
\hline $\begin{array}{l}\text { Pterostichus } \\
\text { anthracinus }\end{array}$ & 0 & 3 & 0 & 0 & 0 & 0 & 0 & oevers \\
\hline Chlaenius nigricornis & 1 & 8 & 0 & 0 & 0 & 0 & 0 & oevers \\
\hline Agonum marginatum & 0 & 0 & 0 & 0 & 0 & 1 & 0 & oevers \\
\hline Elaphrus riparius & 0 & 0 & 0 & 0 & 0 & 1 & 0 & oevers \\
\hline Oodes helopioides & 0 & 3 & 0 & 0 & 0 & 0 & 0 & oevers \\
\hline Stenolophus mixtus & 0 & 1 & 0 & 0 & 0 & 0 & 0 & oevers \\
\hline Carabus granulatus & 5 & 9 & 2 & 3 & 1 & 2 & 2 & vochtig \\
\hline Bembidion articulatum & 0 & 3 & 0 & 0 & 0 & 0 & 0 & vochtig \\
\hline Bembidion guttula & 3 & 0 & 0 & 0 & 0 & 0 & 0 & vochtig \\
\hline Elaphrus cupreus & 0 & 14 & 3 & 0 & 6 & 12 & 0 & vochtig \\
\hline Dyschirius globosus & 1 & 0 & 38 & 26 & 4 & 1 & 0 & vochtig \\
\hline Loricera pilicornis & 1 & 5 & 0 & 9 & 8 & 3 & 0 & vochtig \\
\hline Agonum fuliginosum & 0 & 0 & 0 & 1 & 0 & 0 & 0 & vochtig \\
\hline Pterostichus diligens & 0 & 0 & 0 & 0 & 0 & 1 & 0 & vochtig \\
\hline Pterostichus minor & 0 & 3 & 2 & 0 & 0 & 1 & 0 & vochtig \\
\hline
\end{tabular}




\begin{tabular}{|c|c|c|c|c|c|c|c|c|}
\hline \multirow[t]{2}{*}{ Soort } & \multicolumn{7}{|c|}{ Transect } & \multirow[t]{2}{*}{ Habitat } \\
\hline & IK & BM & OV1 & OV2 & ZB1 & ZB2 & DB & \\
\hline Pterostichus nigrita & 3 & 7 & 0 & 1 & 0 & 1 & 0 & vochtig \\
\hline Notiophilus palustris & 0 & 0 & 1 & 0 & 0 & 0 & 0 & vochtig \\
\hline Anisodactylus binotatus & 0 & 1 & 0 & 0 & 0 & 0 & 0 & vochtig \\
\hline Totaal aantal taxa & 18 & 16 & 18 & 16 & 13 & 17 & 10 & \\
\hline Individuen & 48 & 91 & 80 & 71 & 50 & 60 & 32 & \\
\hline
\end{tabular}

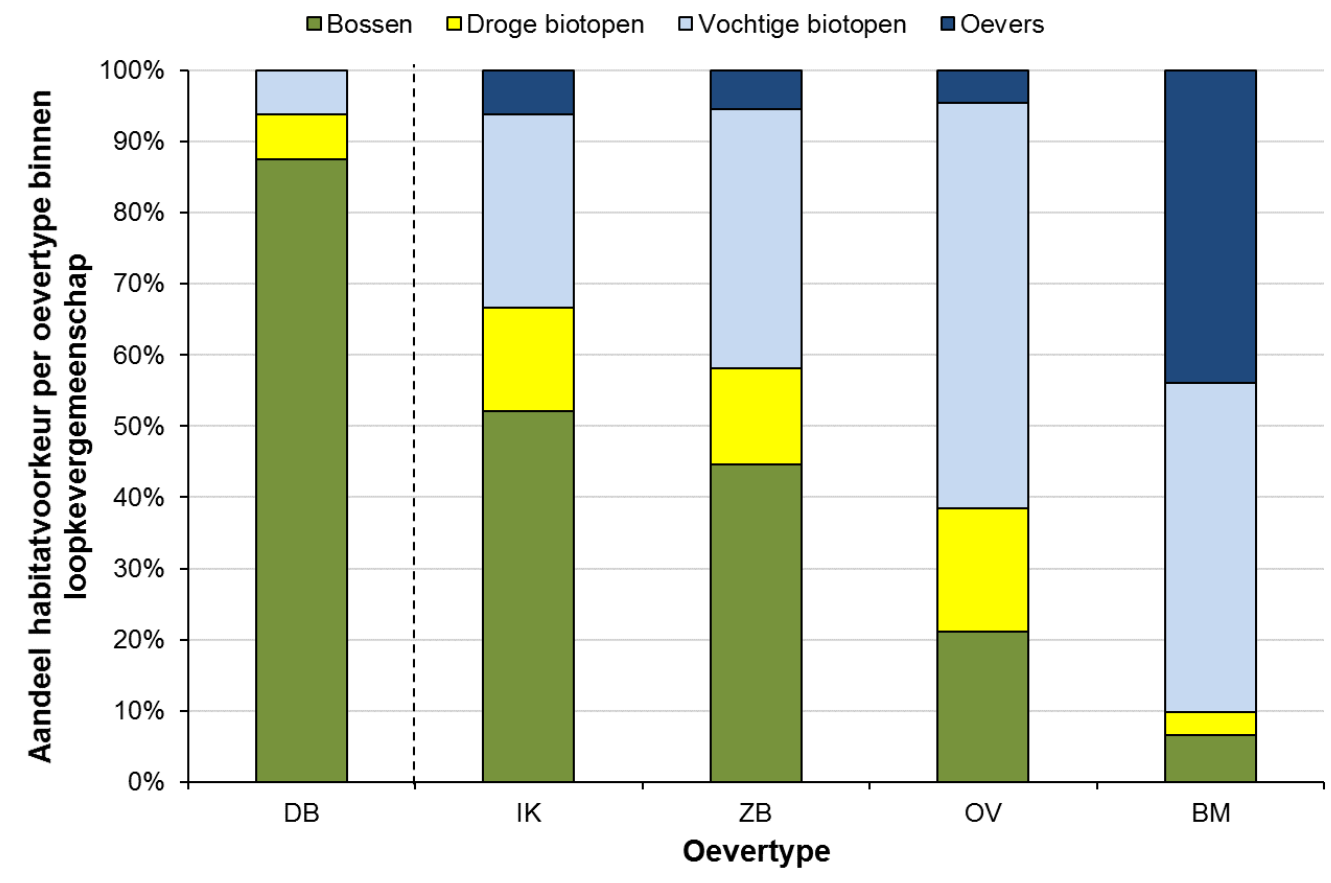

Figuur 11: Habitatvoorkeur loopkevers.

Tabel 5: Samenstelling wolfspinnenfauna oeverzone in juni 2017.

\begin{tabular}{|c|c|c|c|c|c|c|c|c|}
\hline \multirow[t]{2}{*}{ Soort } & \multicolumn{7}{|c|}{ Transect } & \multirow[t]{2}{*}{ Habitat } \\
\hline & IK & BM & OV1 & OV2 & ZB1 & ZB2 & DB & \\
\hline Arctosa leopardus & 0 & 3 & 0 & 0 & 0 & 0 & 0 & oever \\
\hline Pardosa amentata & 0 & 4 & 0 & 0 & 0 & 0 & 0 & vochtig \\
\hline Piratula hygrophila & 13 & 32 & 17 & 7 & 31 & 17 & 7 & vochtig \\
\hline Pirata latitans & 0 & 1 & 0 & 0 & 0 & 0 & 0 & oever \\
\hline Pirata piraticus & 0 & 20 & 6 & 0 & 0 & 0 & 0 & oever \\
\hline Pirata tenuitarsis & 0 & 3 & 1 & 0 & 0 & 0 & 0 & oever \\
\hline Trochosa terricola & 0 & 1 & 0 & 0 & 0 & 0 & 0 & droog \\
\hline Lycosidae (juveniel) & 1 & 3 & 4 & 5 & 0 & 0 & 1 & n.v.t. \\
\hline Totalen & & & & & & & & \\
\hline Soorten & 1 & 7 & 3 & 1 & 1 & 1 & 1 & \\
\hline Individuen & 14 & 67 & 28 & 12 & 31 & 17 & 8 & \\
\hline
\end{tabular}




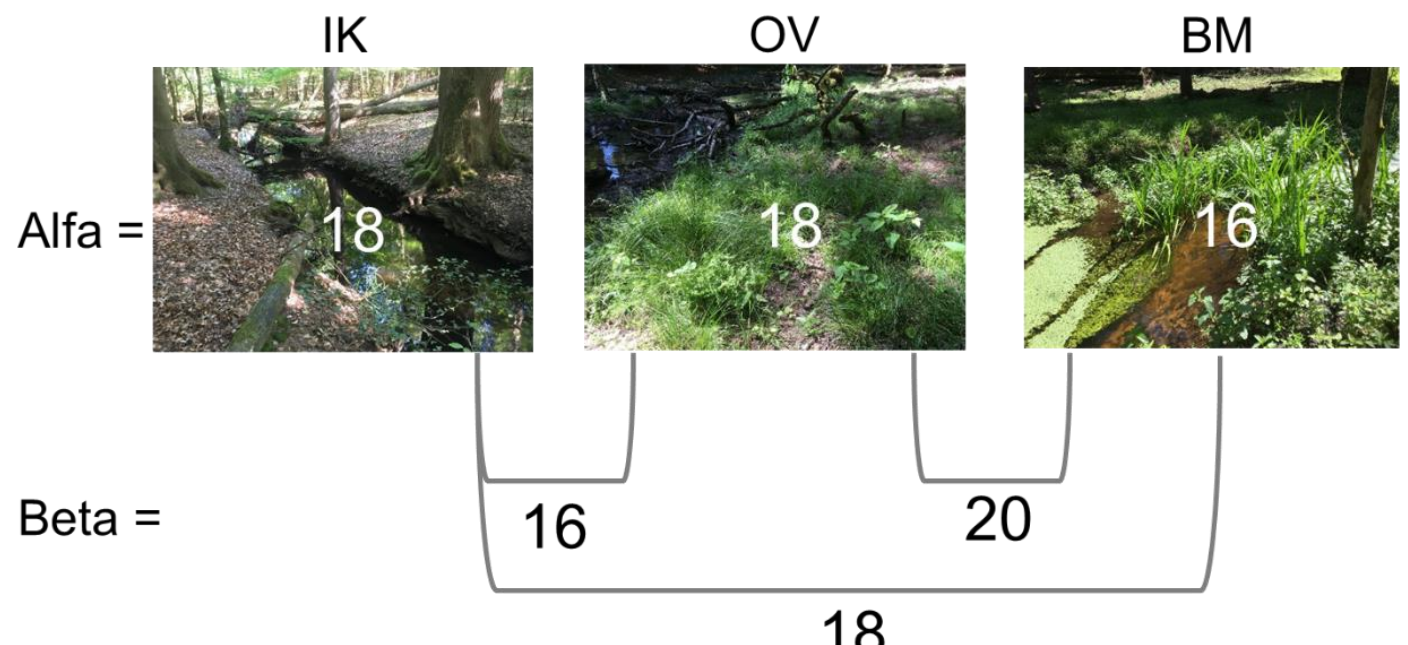

Gamma $=\quad$ Totaal aantal soorten: 31

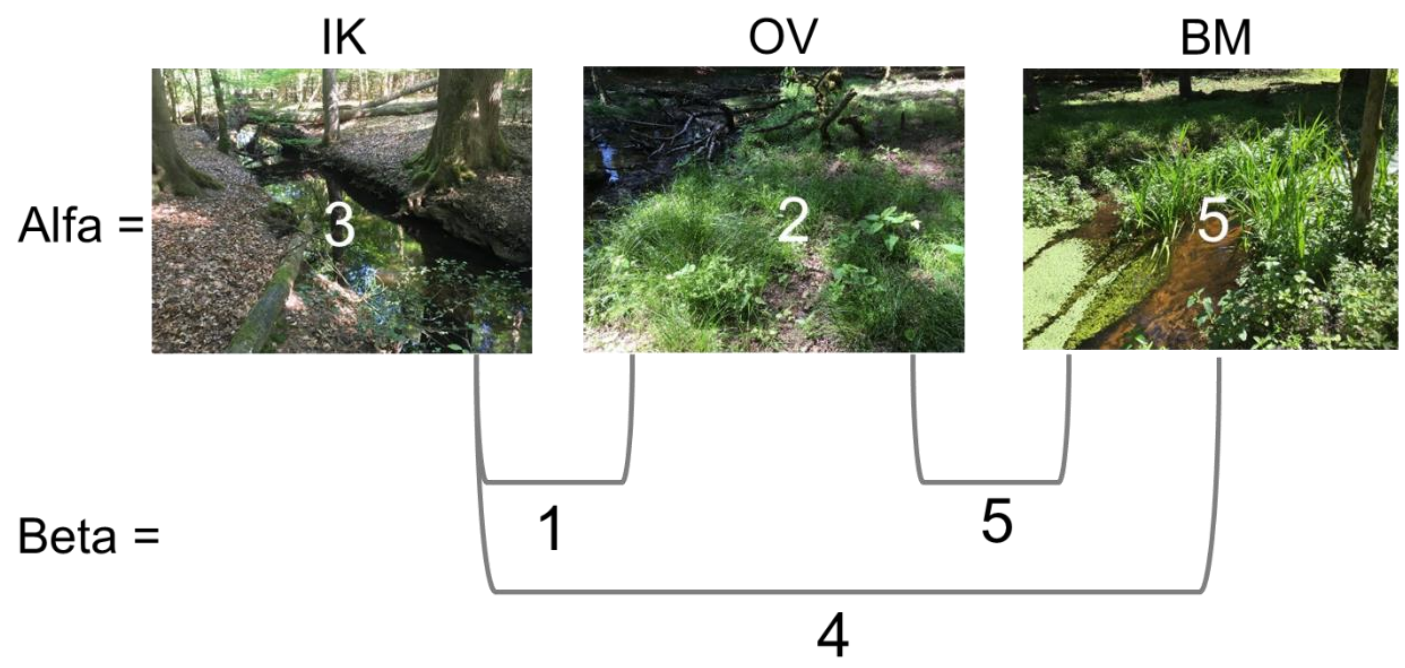

Gamma $=\quad$ Totaal aantal oeversoorten: 6

Figuur 12: Bijdrage van 3 typen oevers aan de totale loopkeverbiodiversiteit voor de totale rijkdom en puur de oeversoorten of semi-terrestrische specialisten.

\section{Conclusies}

\section{Dwarsprofieltransectmetingen}

Twee jaar na het staken van de suppleties lijken de locaties Z1 en Z3 min of meer gestabiliseerd. Er treedt in het winterhalfjaar nog wel zandtransport op, wat af te leiden valt aan de hand van een tijdelijke kleine ophoging van de bodem gevolgd door terugkeer op het oude bodemhoogteniveau (zomer van 1 jaar eerder). Benedenstrooms van Z2 zijn nog wel veranderingen waar te nemen. Dit is overigens ook de enige meetlocatie waar nog duidelijk een zandtong zichtbaar is.

\section{Vegetatie}

Op de plekken waar beek en beekdal weer met elkaar verbonden zijn en een beekmoeras of overstromingszones zijn ontstaan, terwijl het bladerdek door het afsterven van bomen open is geworden (rondom Z1), is moerasvegetatie massaal aanwezig. Het gaat veelal om 
algemene soorten van natte tot vochtige voedselrijke omstandigheden die al in het gebied aanwezig waren, vaak ook soorten van gestoorde (omgewoelde) bodems. Er zijn zaailingen aangetroffen van beekbegeleidende bomen in zowel het beekmoeras als de overstromingszones (Wilg, Fladderiep), maar niet van Zwarte Els. Het is te verwachten dat de toename van moerasvegetatie een belangrijke functie heeft voor het gebied, bijvoorbeeld voor bloembezoekende insecten (zeer bloemrijke vegetatie) en als voedsel voor zoogdieren.

\section{Oeverfauna}

Het beekmoeras is een hotspot van ongewerveldenbiodiversiteit, hier komen veel loopkeveren wolfsspinnensoorten voor die niet op andee type oevers worden aangetroffen. Echte beeksoorten zijn niet aangetroffen, ook niet op de zandbanken langs de beek.

\section{Aanbevelingen}

\section{Dwarsprofieltransectmetingen}

Nog niet alle trajecten zijn stabiel. Geadviseerd wordt de metingen daarom vooralsnog in de huidige frequentie (1x voorjaar, $1 x$ najaar) voort te zetten. Van het invallen van een boomkruin in traject Z2 kan geleerd worden wat de effecten hiervan zijn op de bodemhoogte/aanzanding. Ter hoogte van Z1 lijkt de vegetatiebedekking door het afsterven van bomen direct langs de beek toe te nemen. In dit kader is het is interessant dit traject te blijven volgen, mogelijk zet dit een nieuwe bodemophoging in gang net zoals bovenstrooms in het beekmoeras plaatsvindt.

\section{Vegetatie}

Dit jaar is voor de eerste keer de vegetatie vastgelegd. Er zijn allerlei soorten moerasplanten verschenen in de vernatte trajecten en ook al wat zaailingen van beekbegeleidende bomen. Het is de vraag hoe deze vegetatie zich verder gaat ontwikkelen, treedt er bijvoorbeeld een overgang op naar een situatie met minder storingssoorten, verschijnen er ook soorten die minder voedselrijke omstandigheden indiceren en hoe ontwikkelen de wilgenzaailingen zich (struweelvorming)? De ontwikkelingen verlopen opvallend snel; het is daarom belangrijk dit te blijven volgen. Aandachtspunt is het vooralsnog ontbreken van zaailingen van Zwarte Els. Dit is de belangrijkste beekbegeleidende boom langs laaglandbeken (structuurvormer, habitat, voedingsbron etc.), het zou daarom wenselijk zijn dat deze soort zich ook in het beekmoeras en in de overstromingszones vestigt.

\section{Oeverfauna}

De moerasontwikkelingen in het bos werken sterk biodiversiteitsverhogend en er zijn allerlei soorten aanwezig die aan dit type habitats gebonden zijn. Echter, echte beeksoorten zijn vooralsnog niet gevonden. Dit ondanks dat een van de belangrijke habitats voor deze soorten, zandbanken, door de zandsuppleties wel aanwezig zijn in het gebied. Dit verdient aandacht, het is namelijk de vraag of dit een kwestie is van tijd (zandbanken nog te jong) of dat er iets anders aan de hand is (habitatkwaliteit niet op orde, te veel verstoringen). Om hier meer inzicht in te krijgen zou het nuttig zijn de monitoring van de semi-terrestrische fauna voort te zetten. 


\section{Literatuur}

Januschke, K. \& R.C.M. Verdonschot, 2016. Effects of river restoration on riparian ground beetles (Coleoptera: Carabidae) in Europe. Hydrobiologia 769: 93-104.

Hering, D., Aroviita, J., Baattrup-Pedersen, A., Brabec, K., Buijse, T., Ecke, F., Friberg, N., Gielczewski, M., Januschke, K., Köhler, J., Kupilas, B., Lorenz, A.W., Muhar, S., Paillex, A., Poppe, M., Schmidt, T., Schmutz, S., Vermaat, J., Verdonschot, P.F.M., Verdonschot, R.C.M., Wolter, C. \& J. Kail, 2015. Contrasting the roles of section length and instream habitat enhancement for river restoration success: a field study on 20 European restoration projects. Journal of Applied Ecology 52: 1518-1527.

Januschke, K., S. Brunzel, P. Haase \& D. Hering, 2011. Effects of stream restorations on riparian mesohabitats, vegetation and carabid beetles. Biodiversity and Conservation 20: 3147-3164.

Lambeets, K., M. L. Vandegehuchte, J.-P. Maelfait \& D. Bonte, 2008. Understanding the impact of flooding on trait-displacements and shifts in assemblage structure of predatory arthropods on river banks. Journal of Animal Ecology 77: 1162-1174.

Lambeets, K., M. L. Vandegehuchte, J.-P. Maelfait \& D. Bonte, 2009. Integrating environmental conditions and functional life-history traits for riparian arthropod conservation planning. Biological Conservation 142: 625-637.

Rainio, J. \& J. Niemelä, 2003. Ground beetles (Coleoptera: Carabidae) as bioindicators. Biodiversity and Conservation 12: 487-506.

te Linde, B., van den Berg, L.-J., Simmelink, M. \& R. van Rosmalen, 2015. Vegetatie en Soortenkartering Leuvenumse Bossen 2014. Stichting Berglinde, in opdracht van Natuurmonumenten Gelderland.

Verdonschot, R.C.M., Dekkers, T.B.M. \& P.F.M. Verdonschot, 2017. Monitoring effecten zandsuppletie Leuvenumse beek 2016. Notitie Zoetwatersystemen, Wageningen Environmental Research, Wageningen UR, Wageningen.

Verdonschot, R.C.M., Dekkers, D.D., Besse-Lotoskaya, A.A. \& P.F.M. Verdonschot, 2016a. Zandsuppletie in de Leuvenumse beek: monitoring van de fysische en biologische effecten 2014-2015. Zoetwatersystemen, Alterra Wageningen UR, Wageningen.

Verdonschot, R., Runhaar, H., Buijse, T., Bijkerk, R. \& P. Verdonschot, 2016b. Doorstroommoerassen en moerasbeken. Typebeschrijvingen en ontwikkeling maatlatten voor de biologische kwaliteitselementen. Notitie Zoetwatersystemen, Alterra Wageningen UR, Wageningen. 


\section{Bijlage 1: dwarsprofielen van alle suppletielocaties}

Controle (moerasbeek) traject C1

Ligging transecten $(1 \mathrm{t} / \mathrm{m} 3=\mathrm{a}, 4 \mathrm{t} / \mathrm{m} 6=\mathrm{b}, 7 \mathrm{t} / \mathrm{m} 9=\mathrm{c})$ :

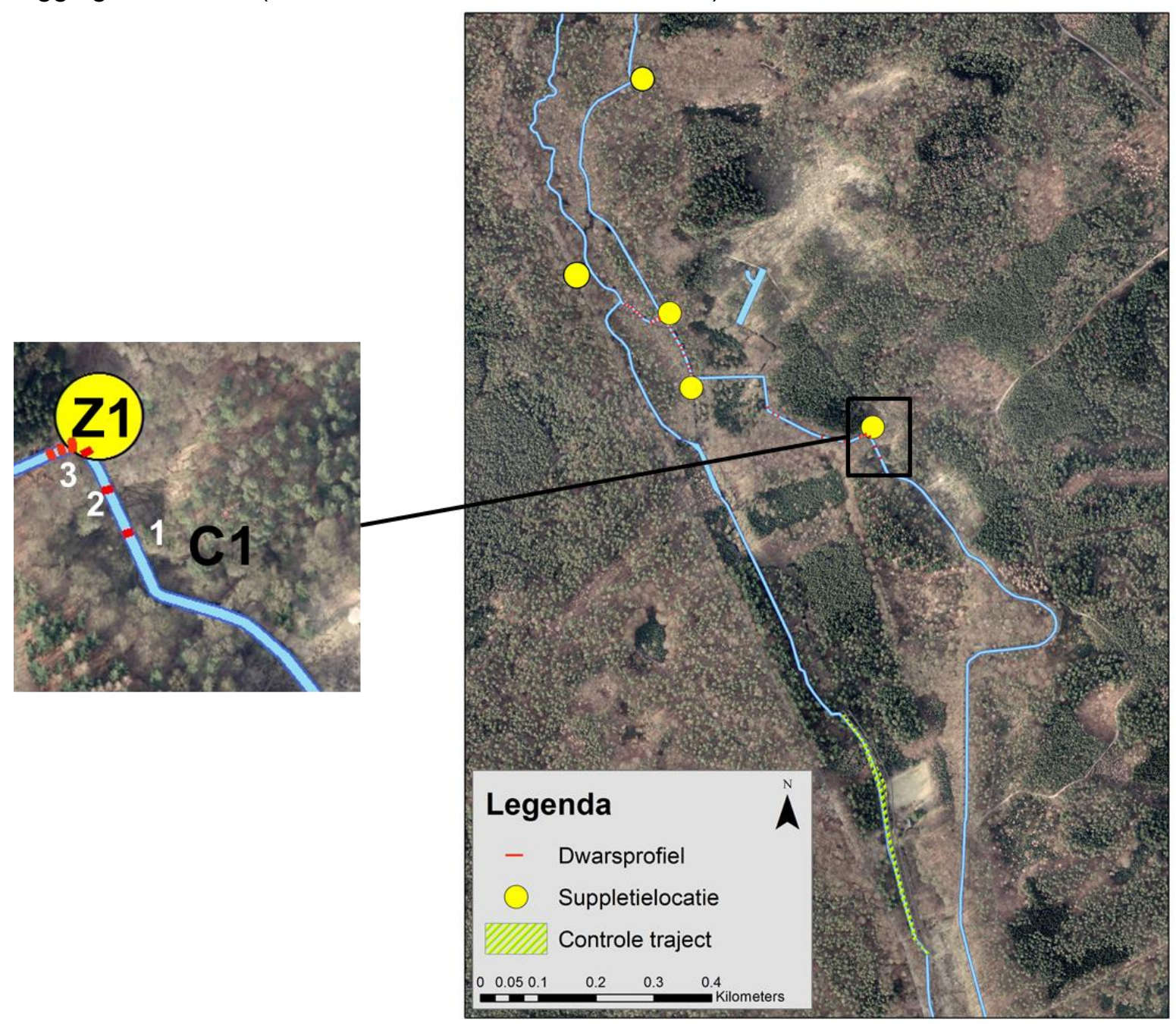



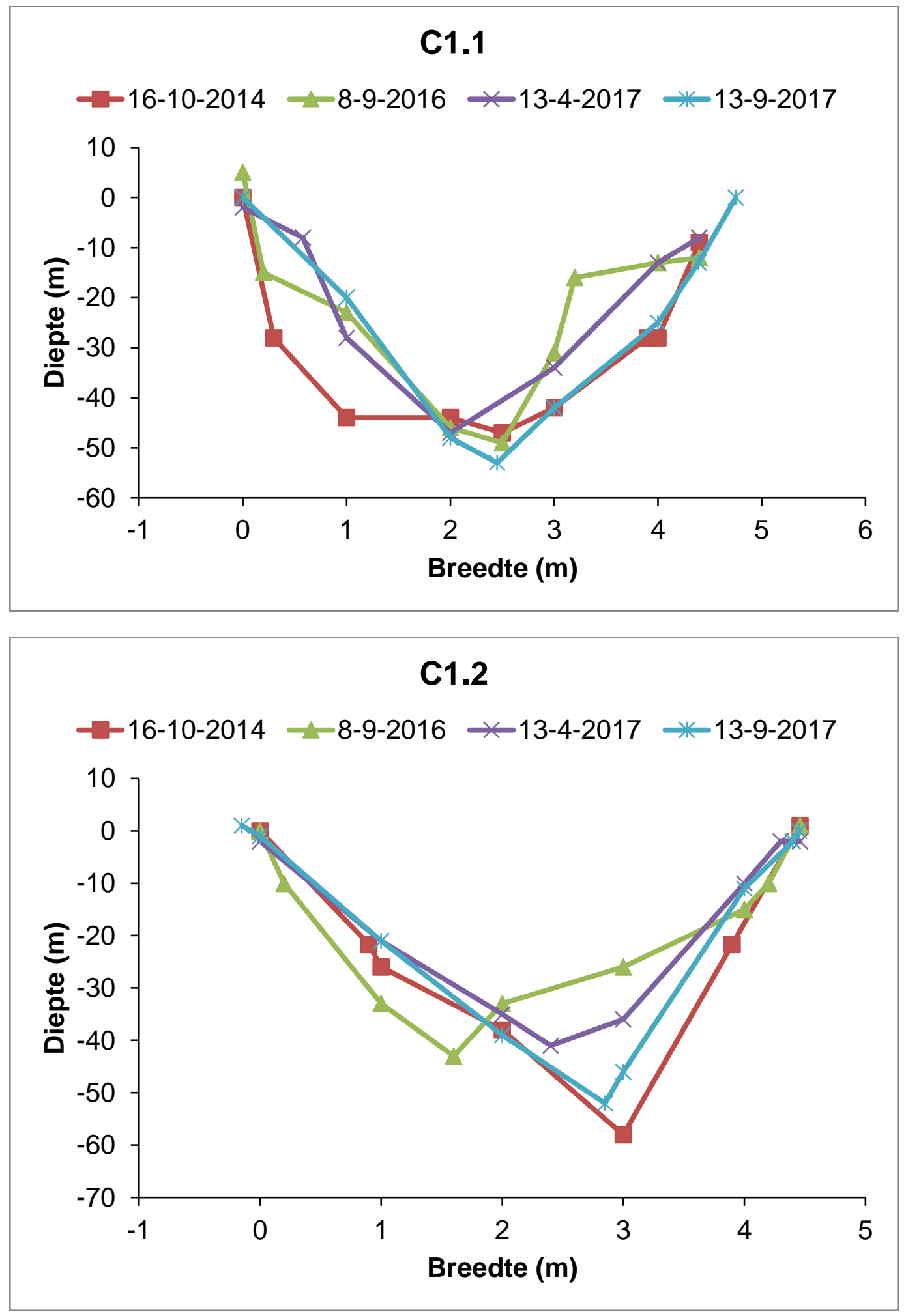


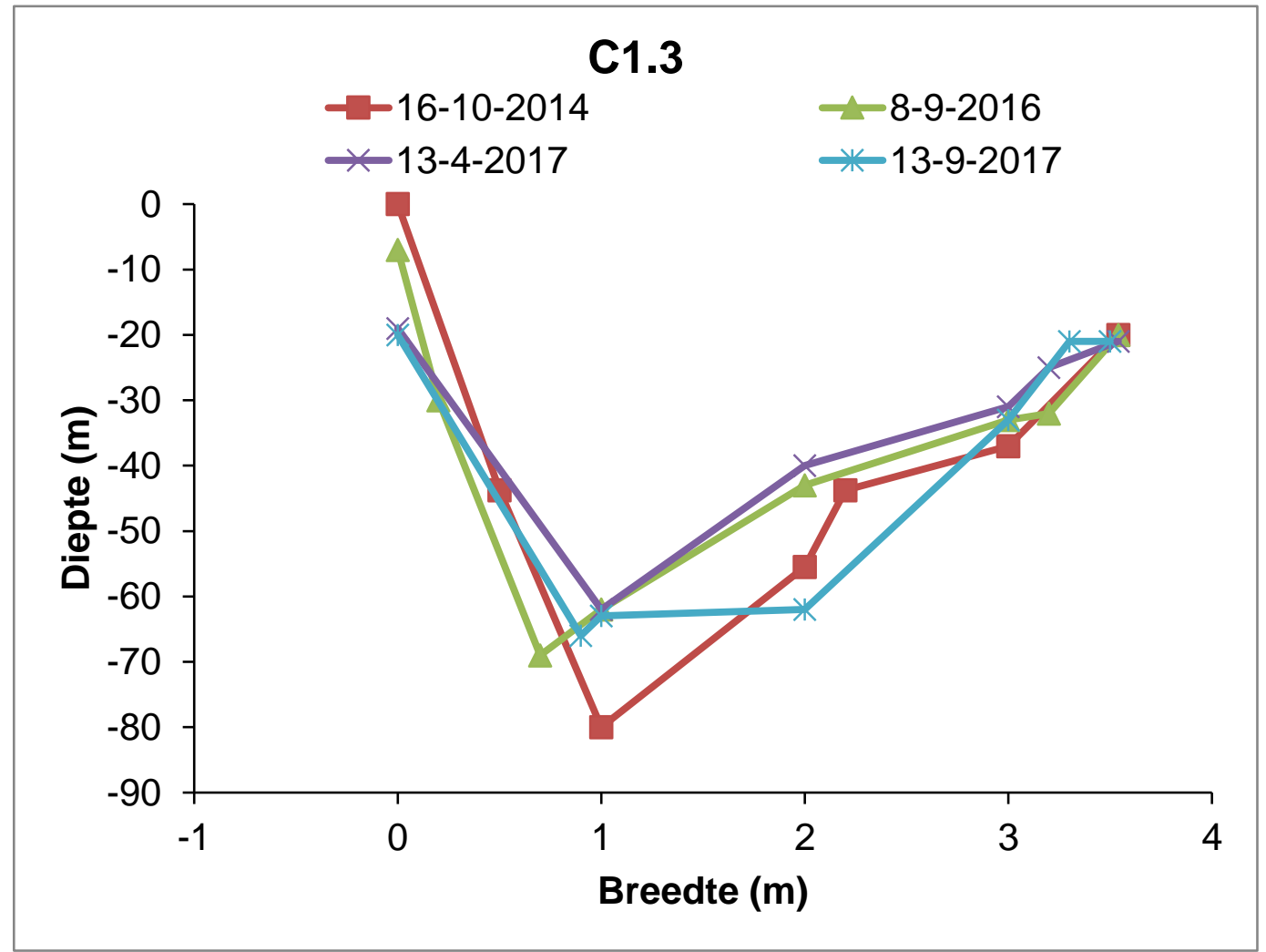




\section{Traject Z1}

Ligging transecten $(1 \mathrm{t} / \mathrm{m} 3=\mathrm{a}, 4 \mathrm{t} / \mathrm{m} 6=\mathrm{b}, 7 \mathrm{t} / \mathrm{m} 9=\mathrm{c})$ :

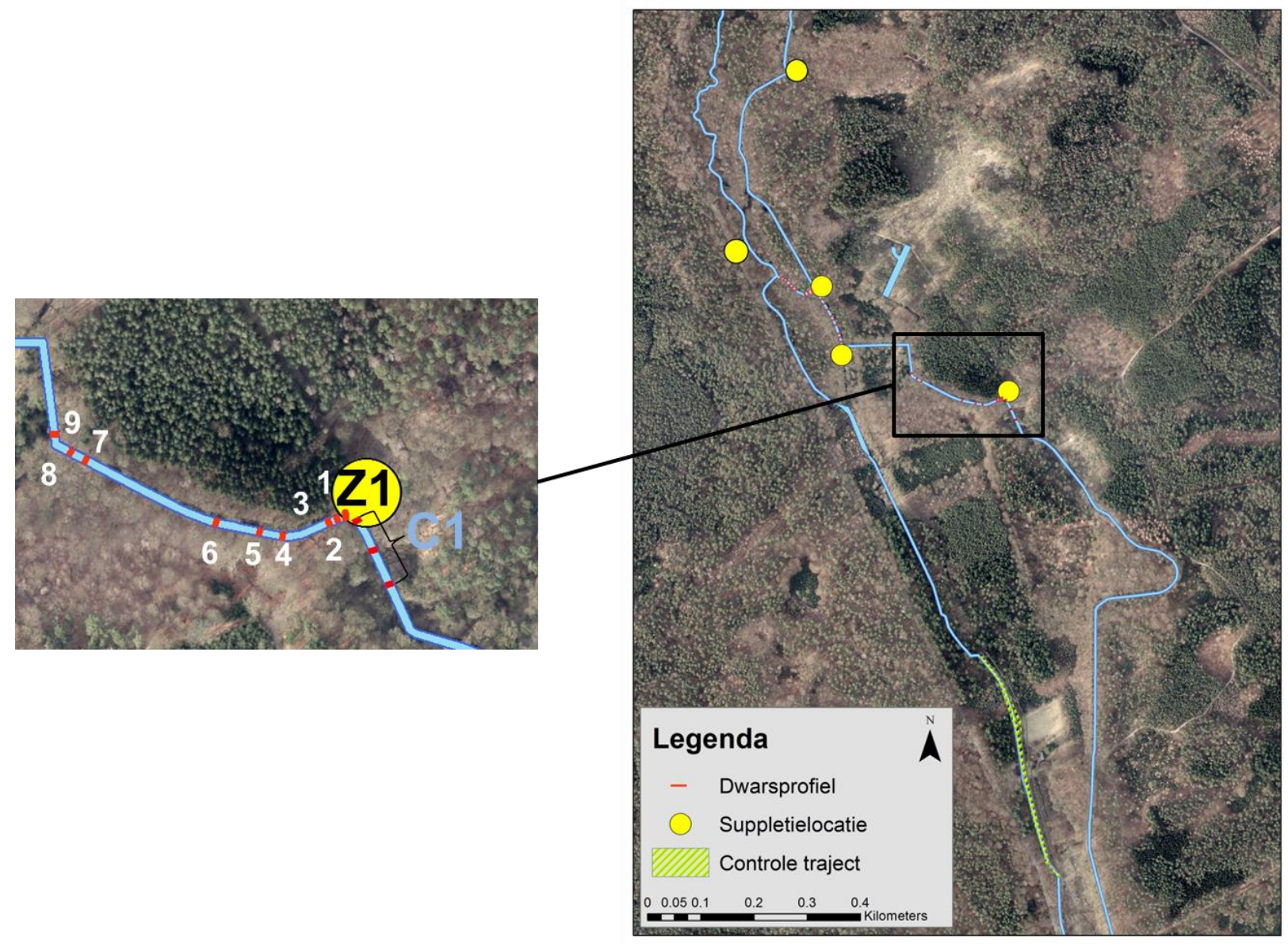



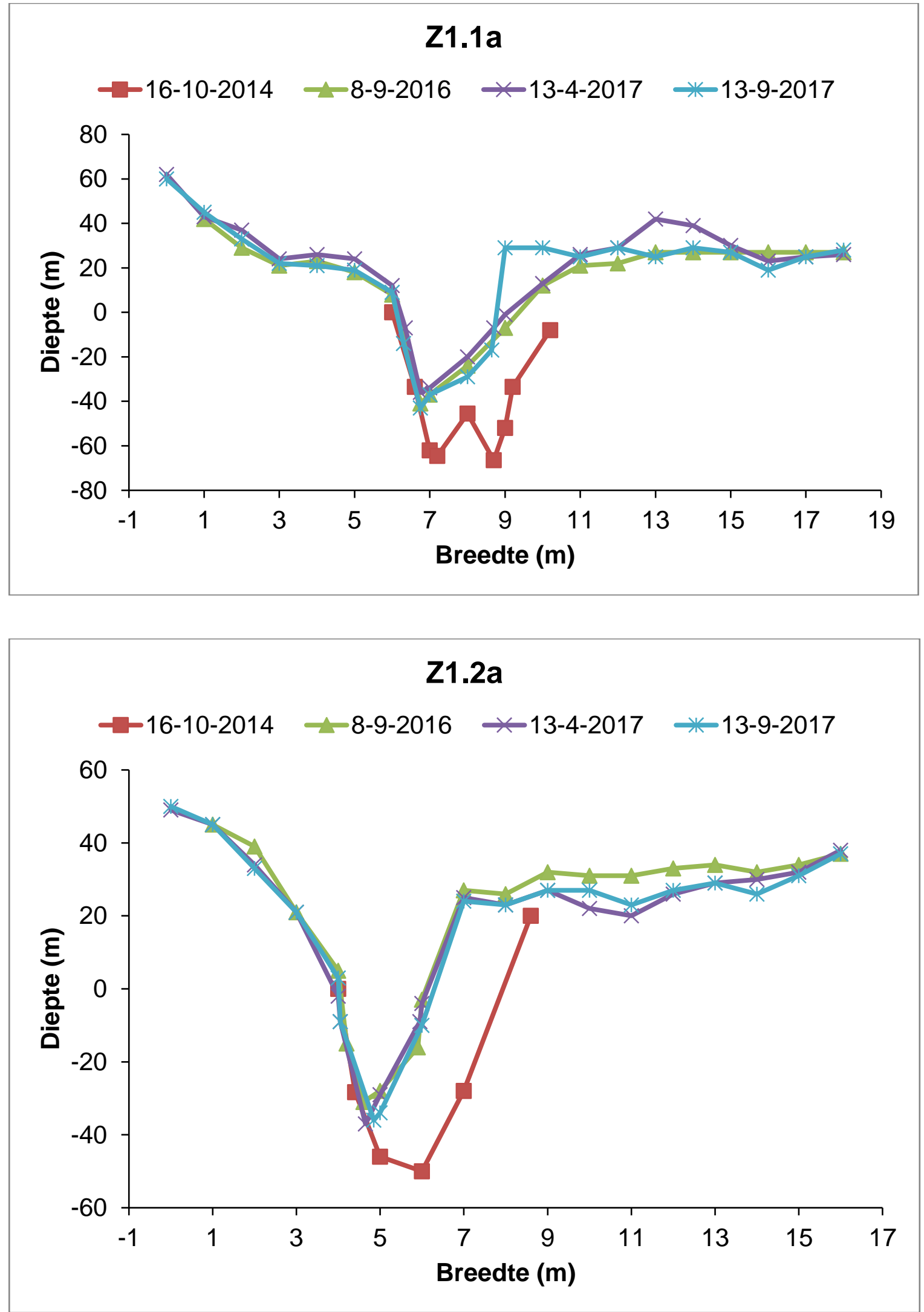

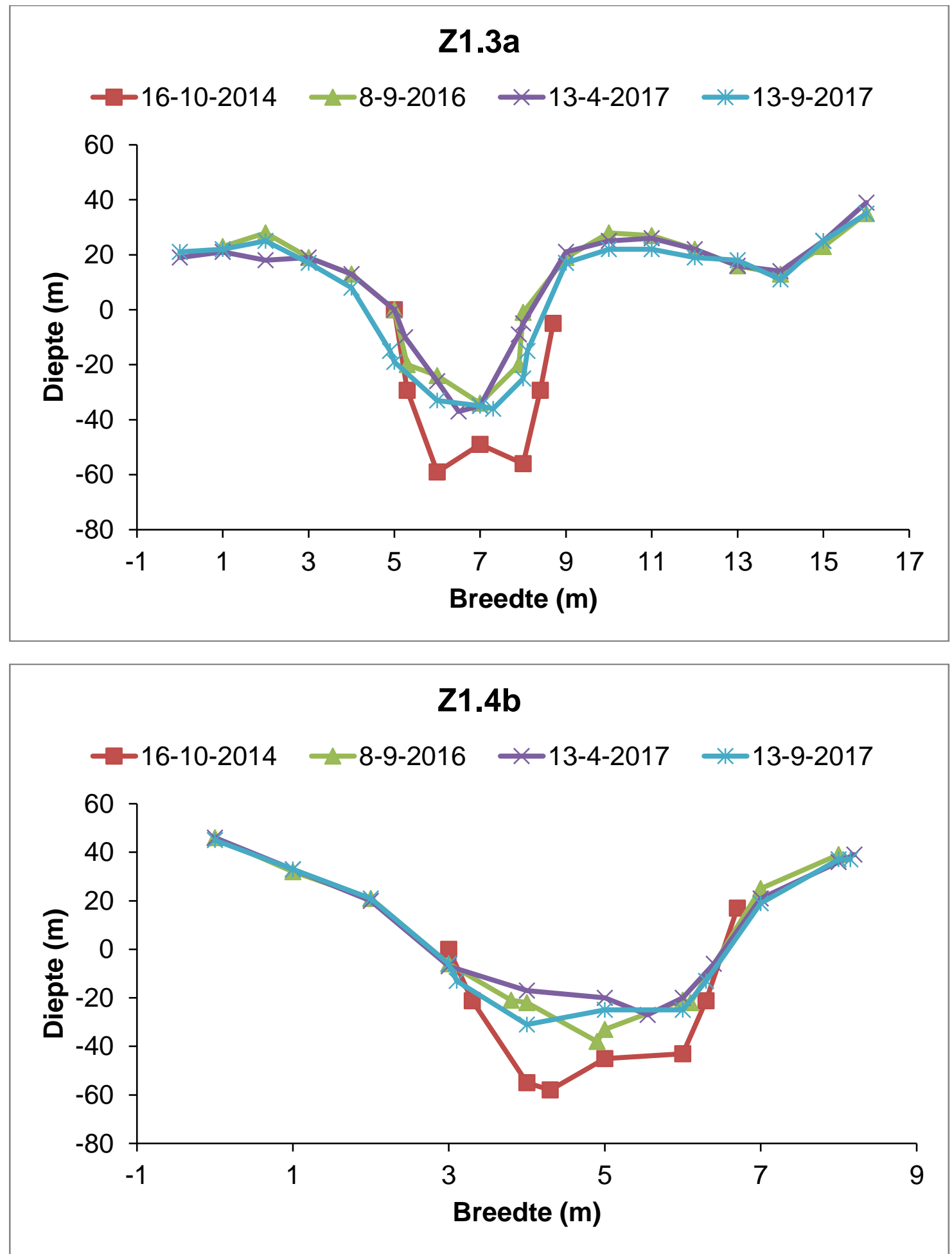


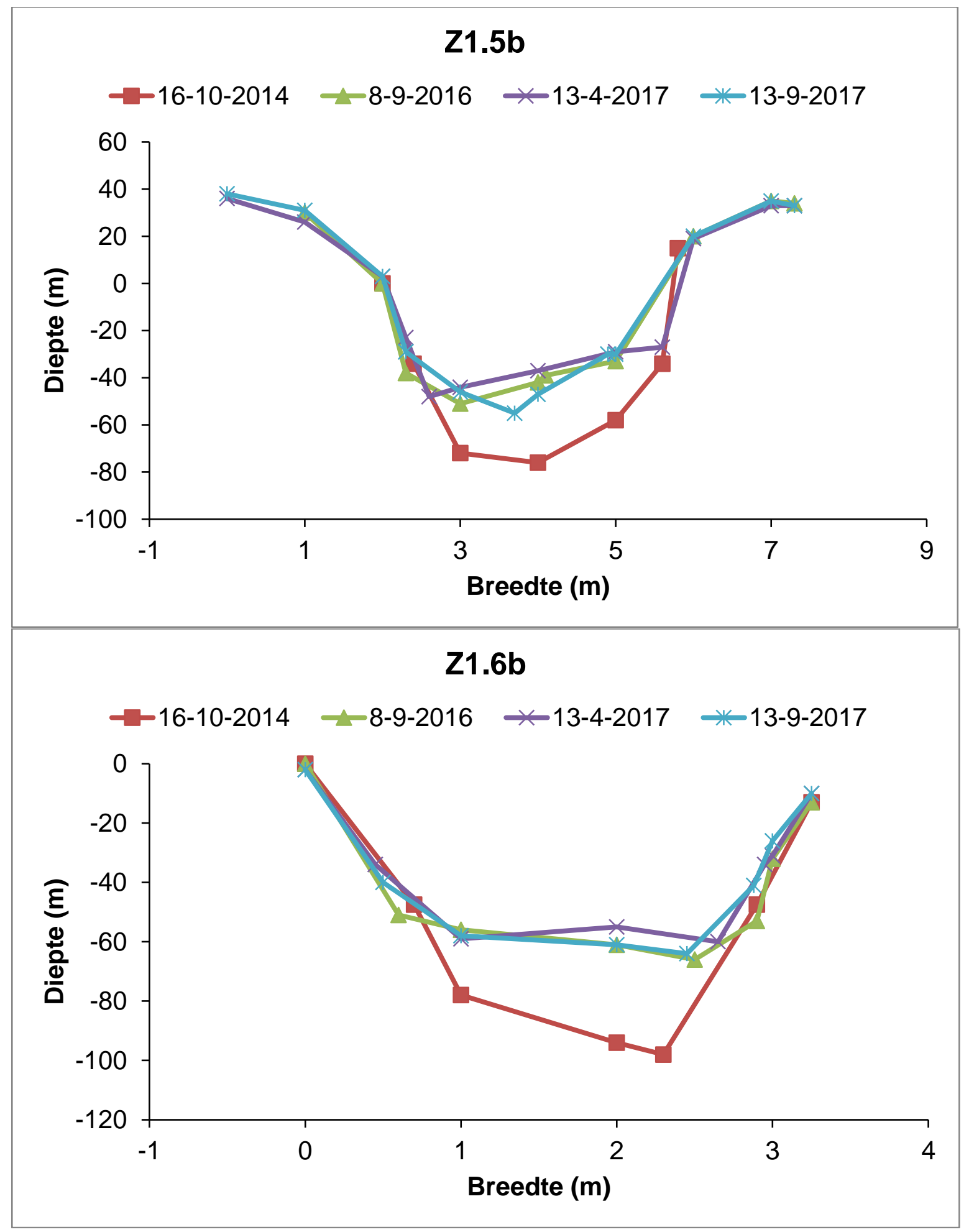




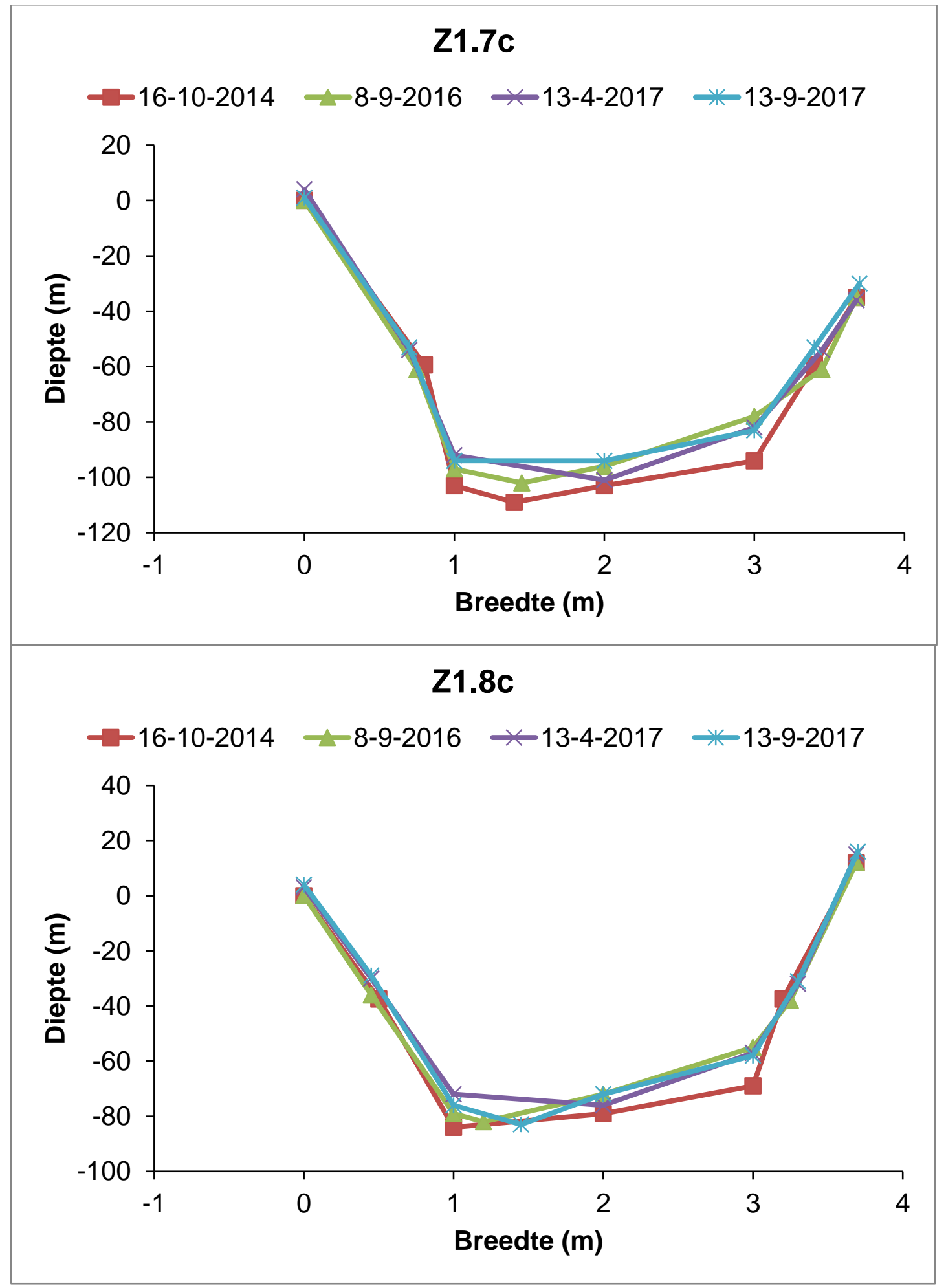




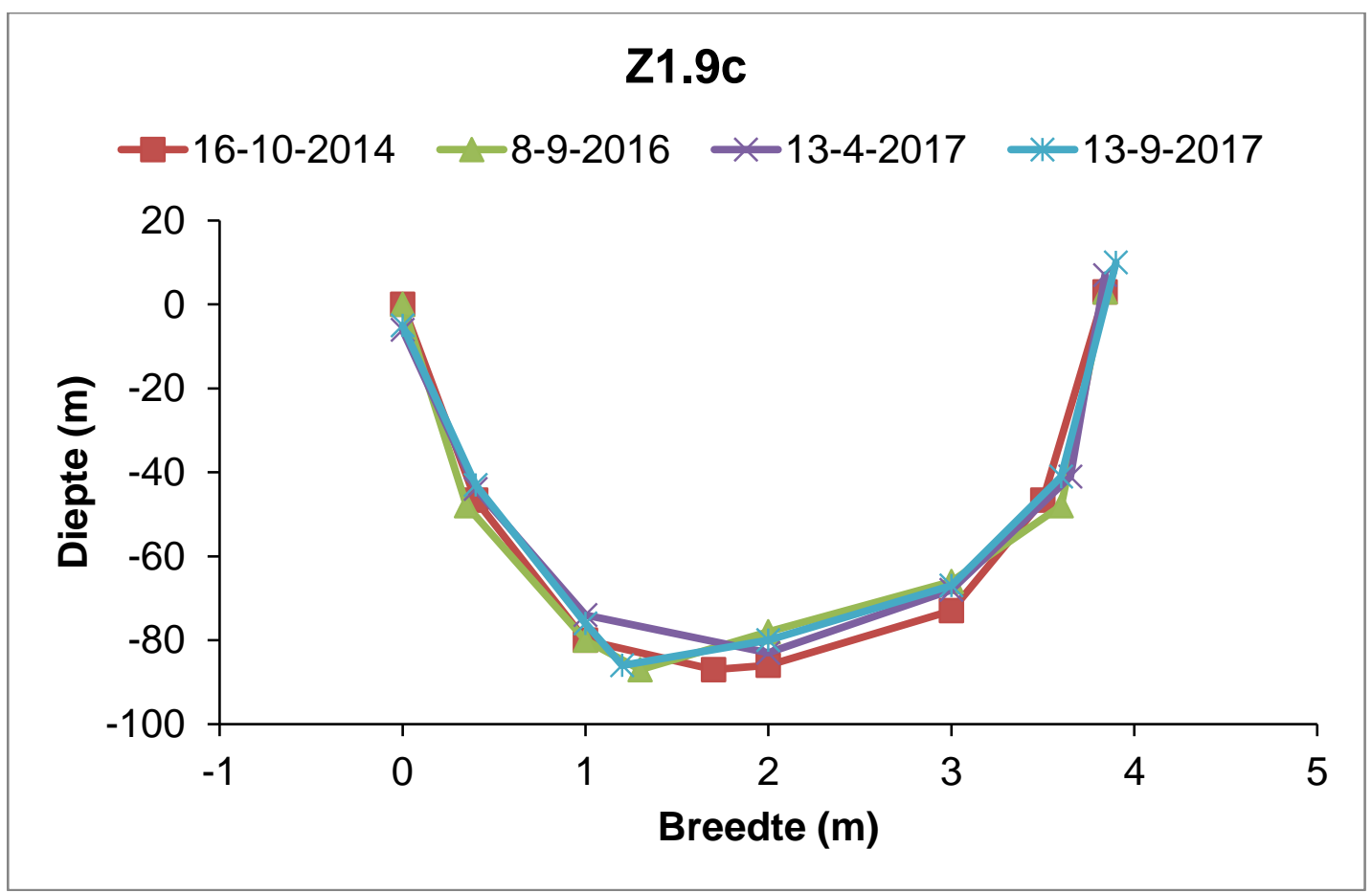




\section{Traject Z2}

Ligging transecten $(1 \mathrm{t} / \mathrm{m} 3=\mathrm{a}, 4 \mathrm{t} / \mathrm{m} 6=\mathrm{b}, 7 \mathrm{t} / \mathrm{m} 9=\mathrm{c})$ :

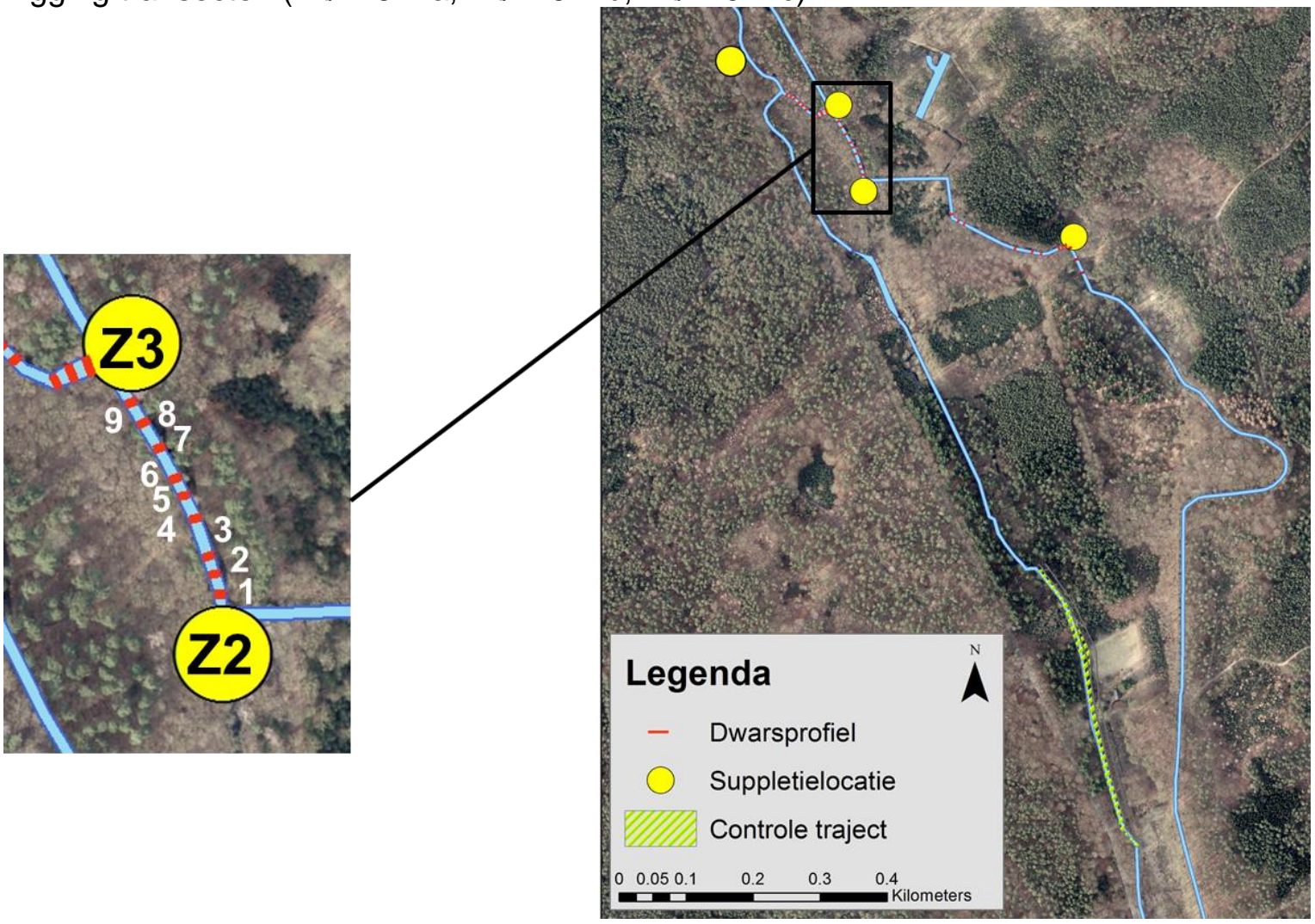




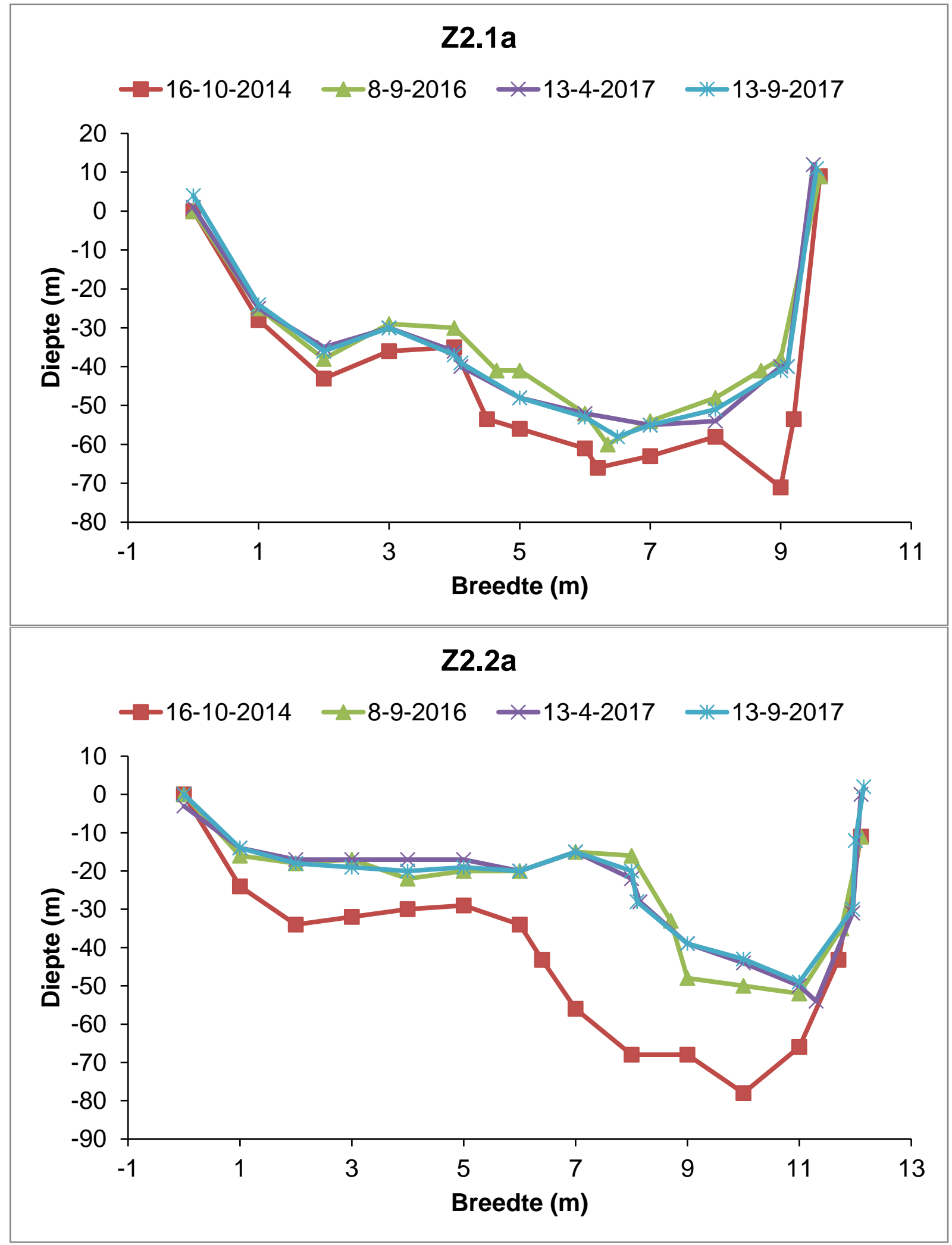




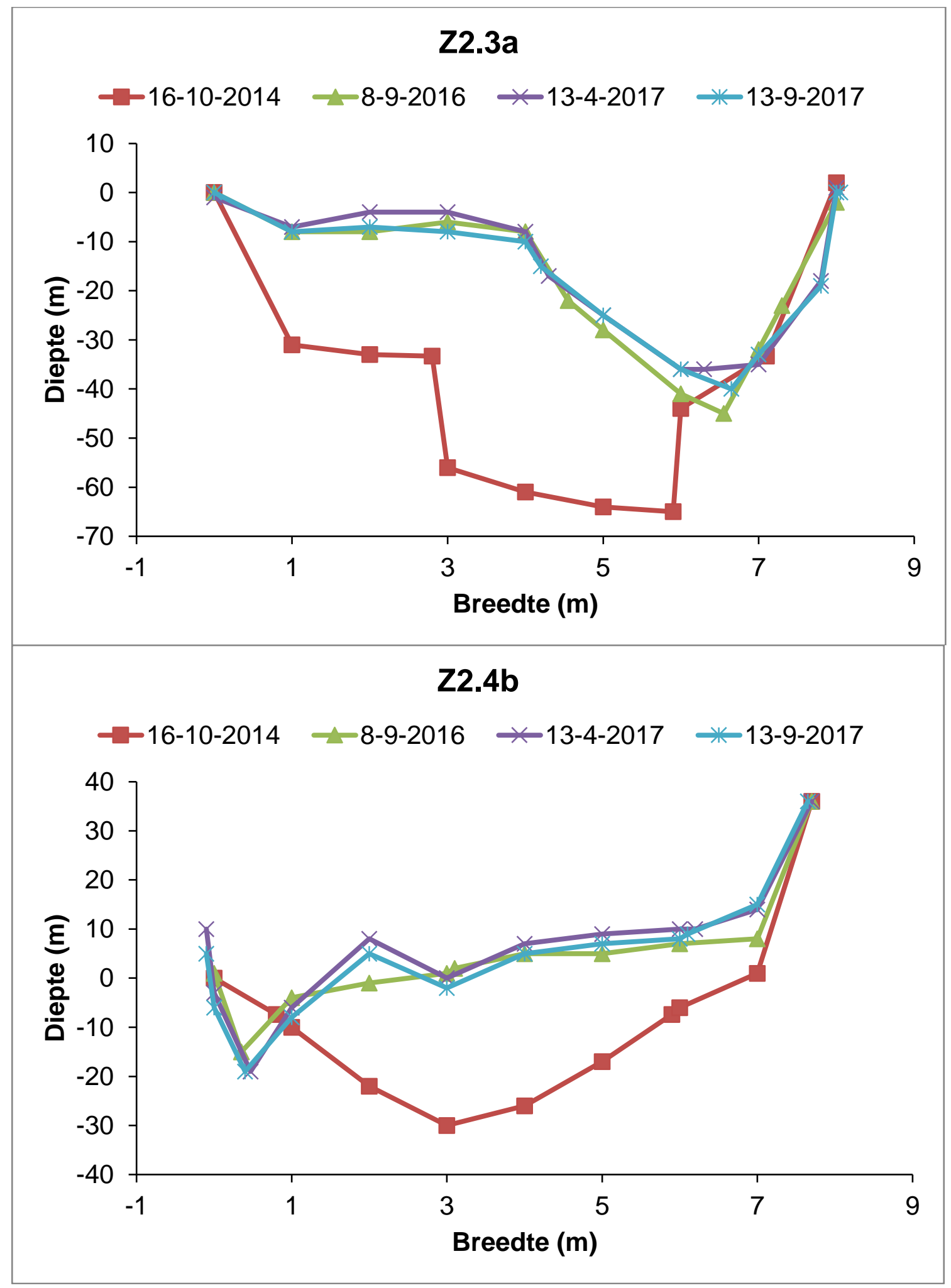




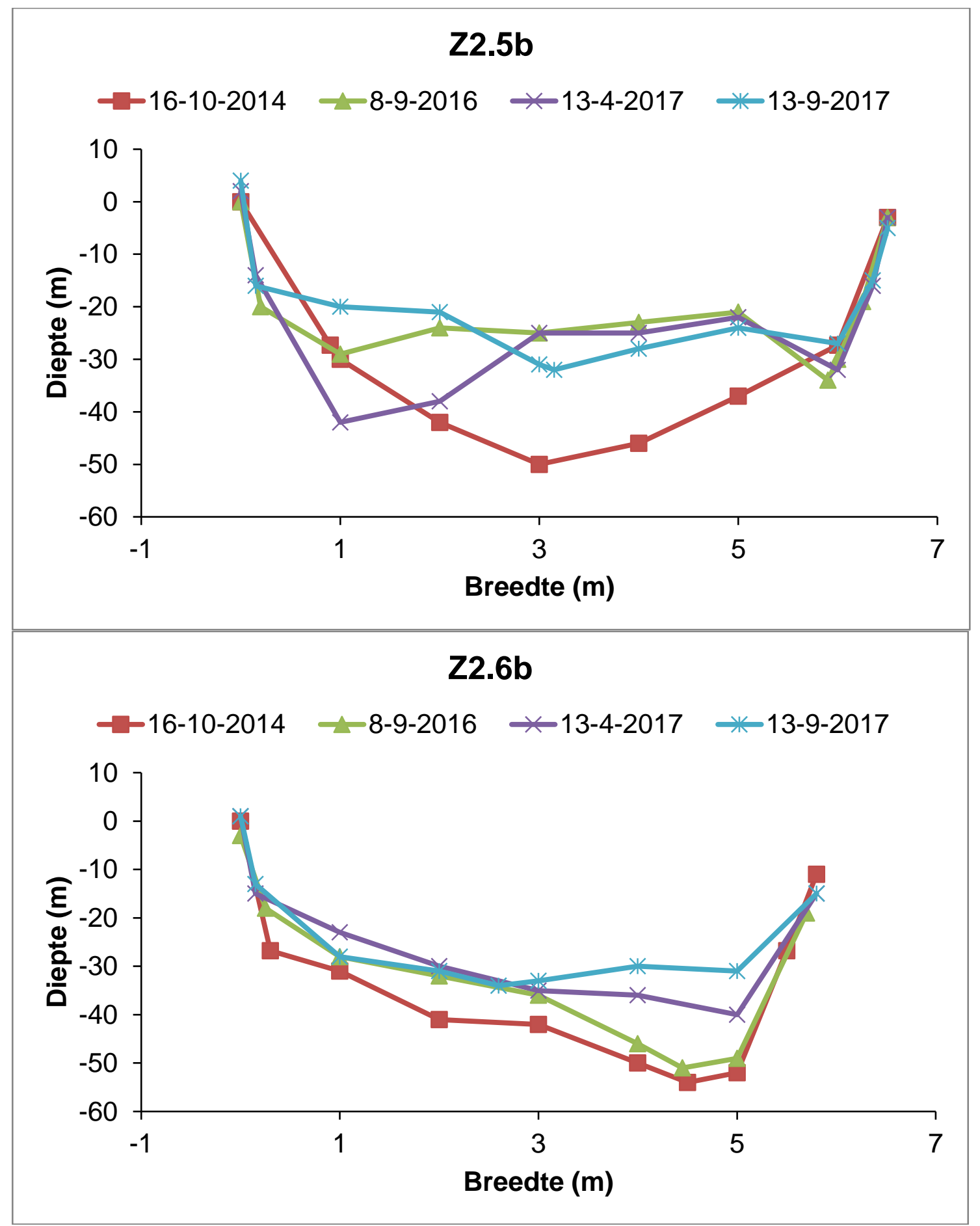



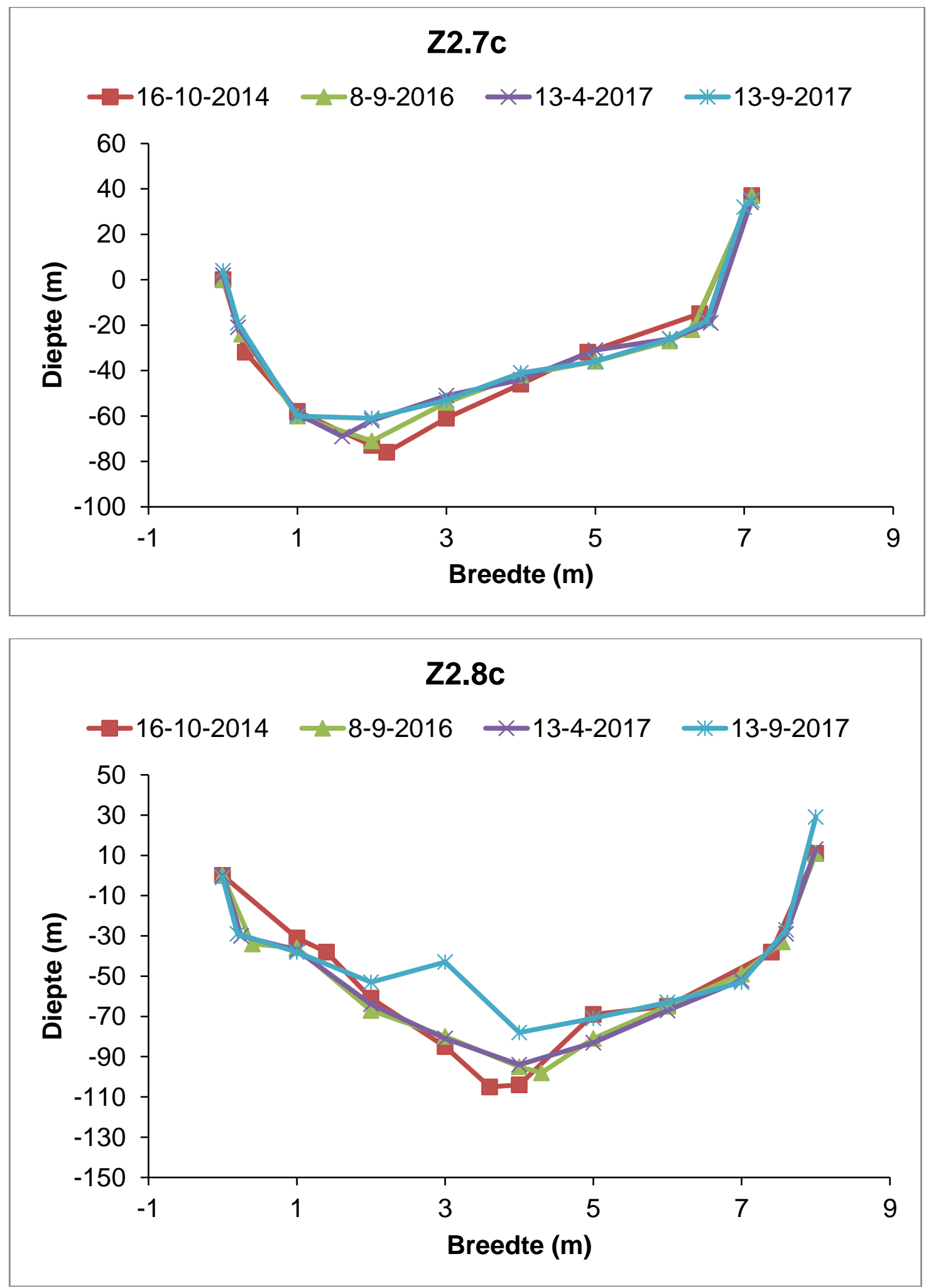

13-9-2017 boomkruin eik in transect gevallen 


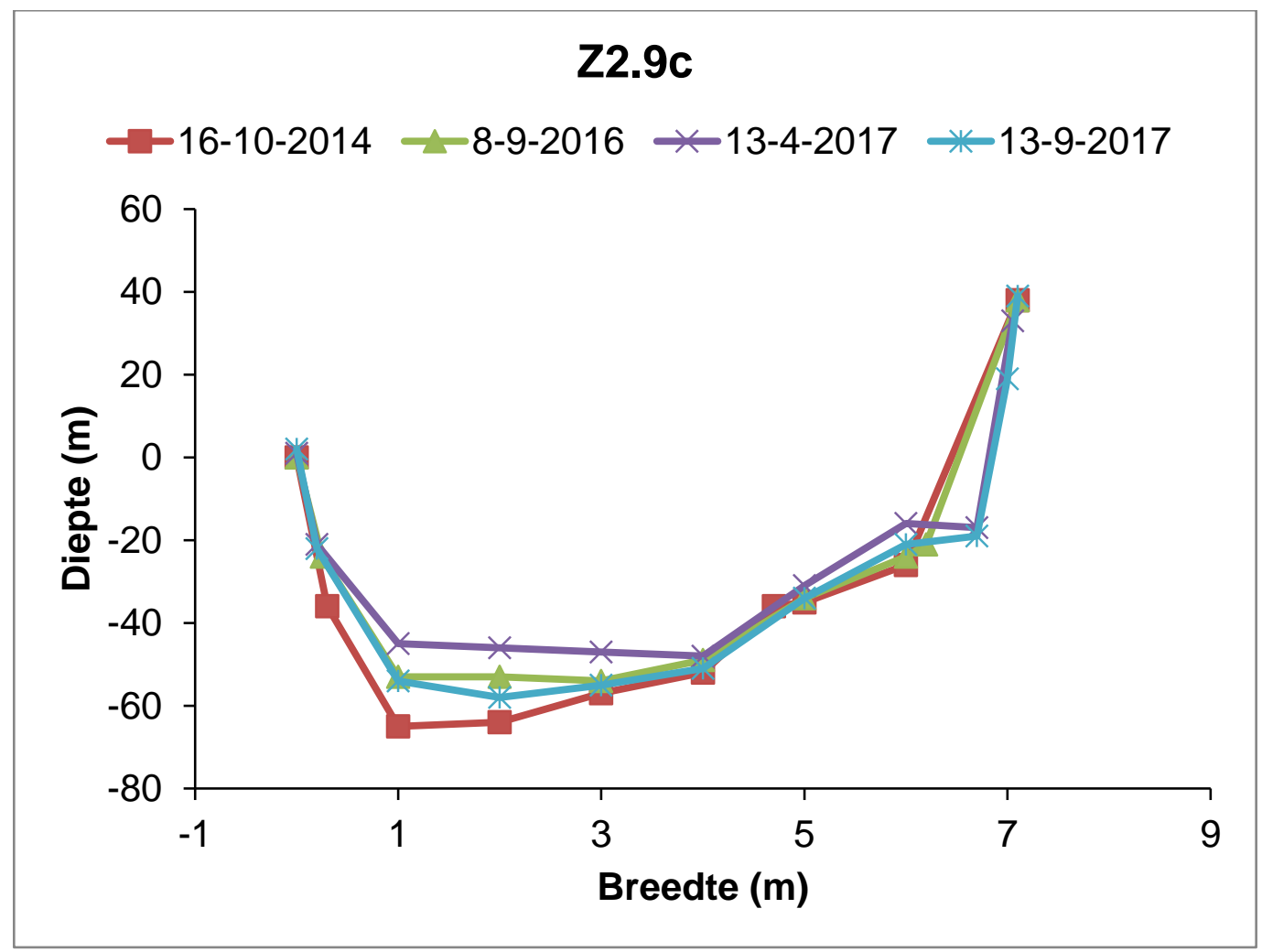




\section{Traject Z3}

Ligging transecten $(1 \mathrm{t} / \mathrm{m} 3=\mathrm{a}, 4 \mathrm{t} / \mathrm{m} 6=\mathrm{b}, 7 \mathrm{t} / \mathrm{m} 9=\mathrm{c})$ :

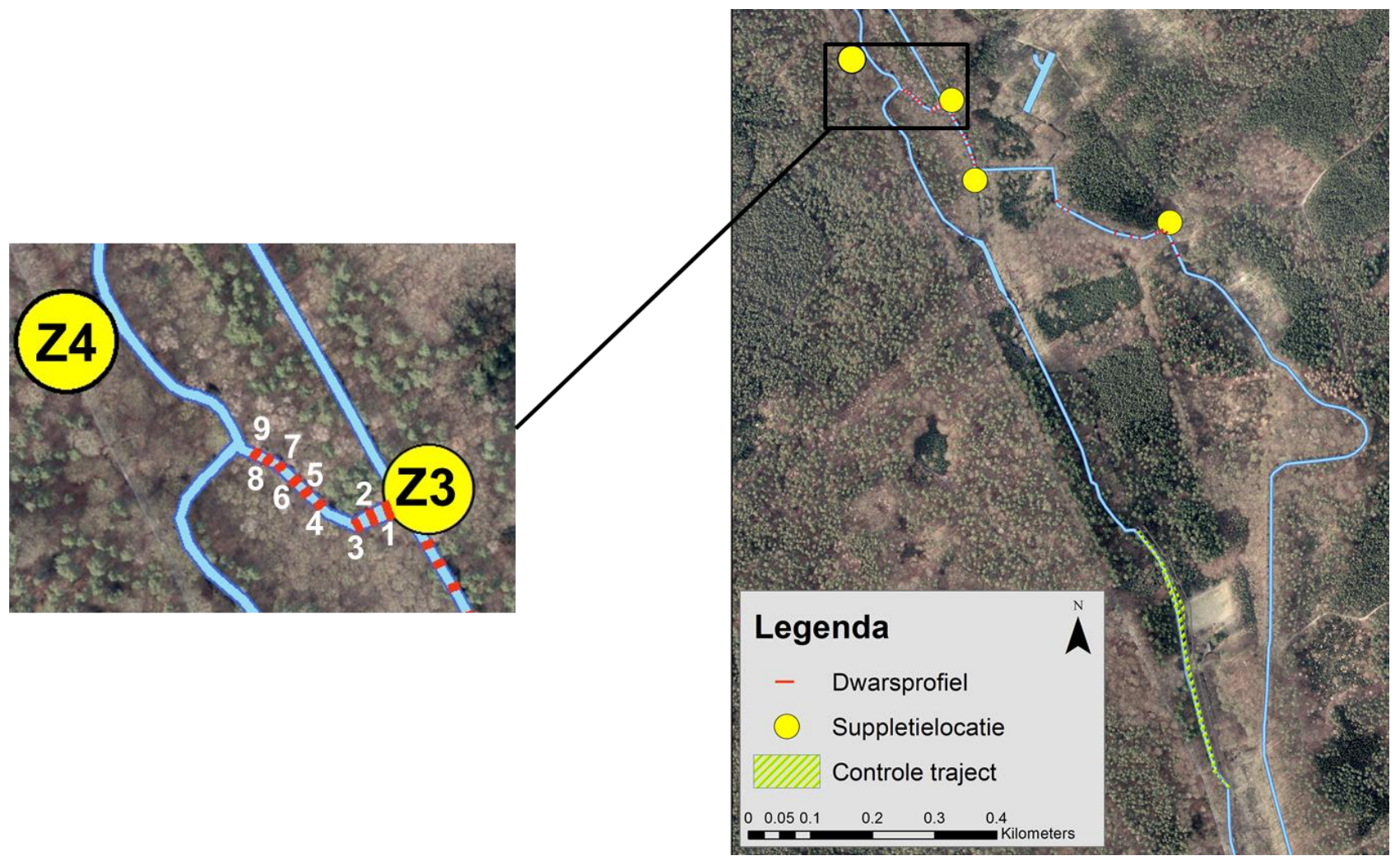



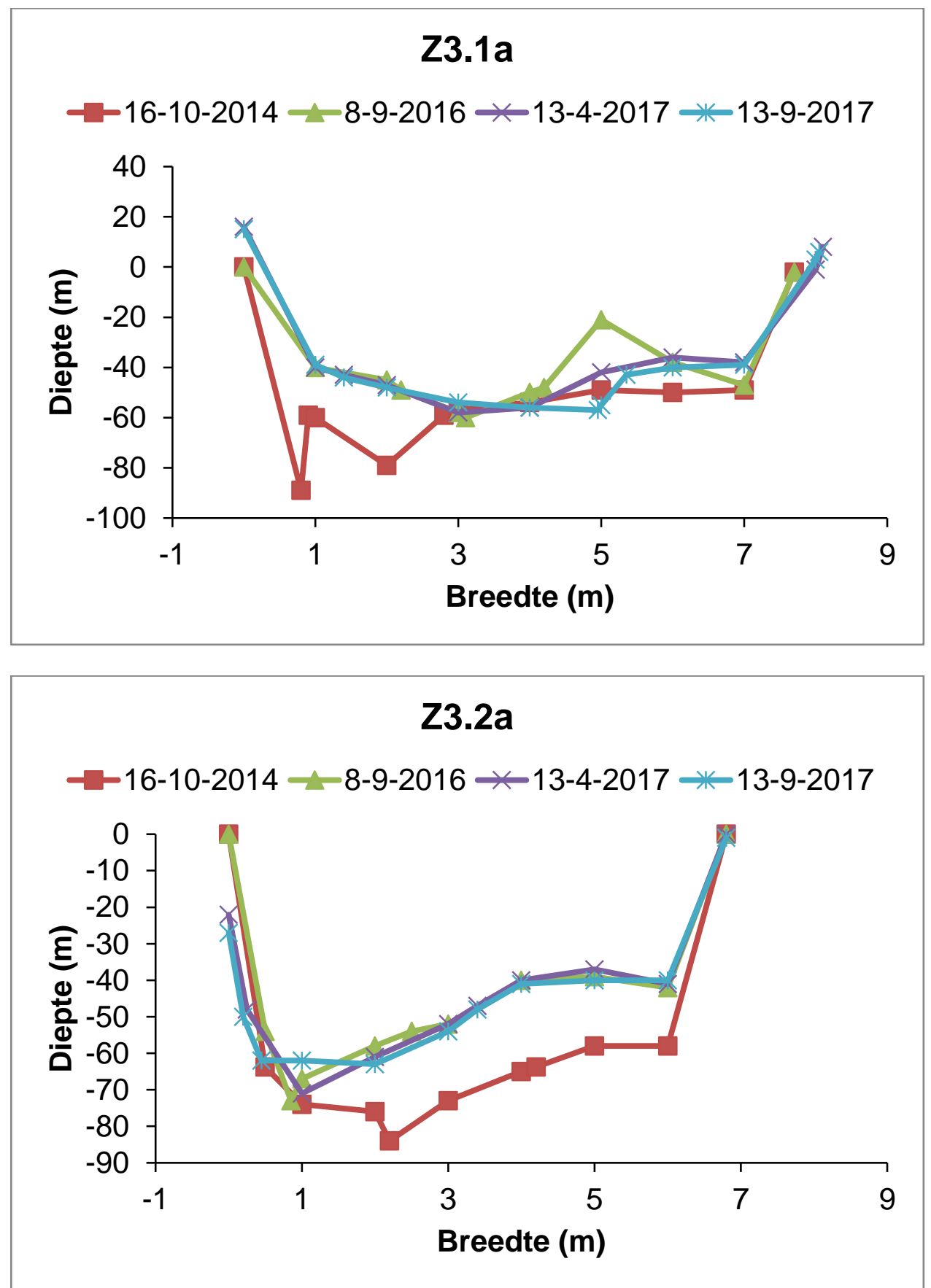

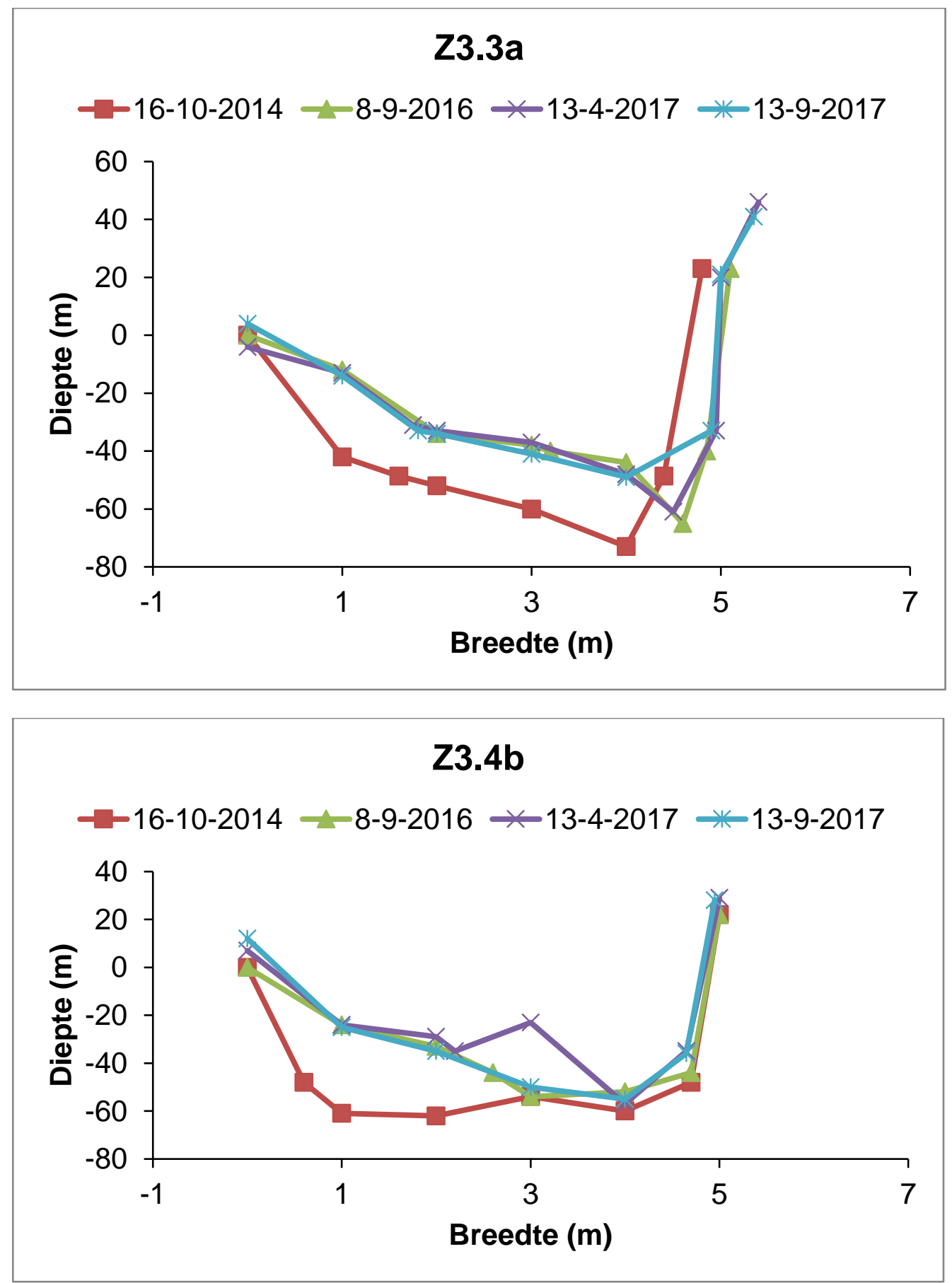

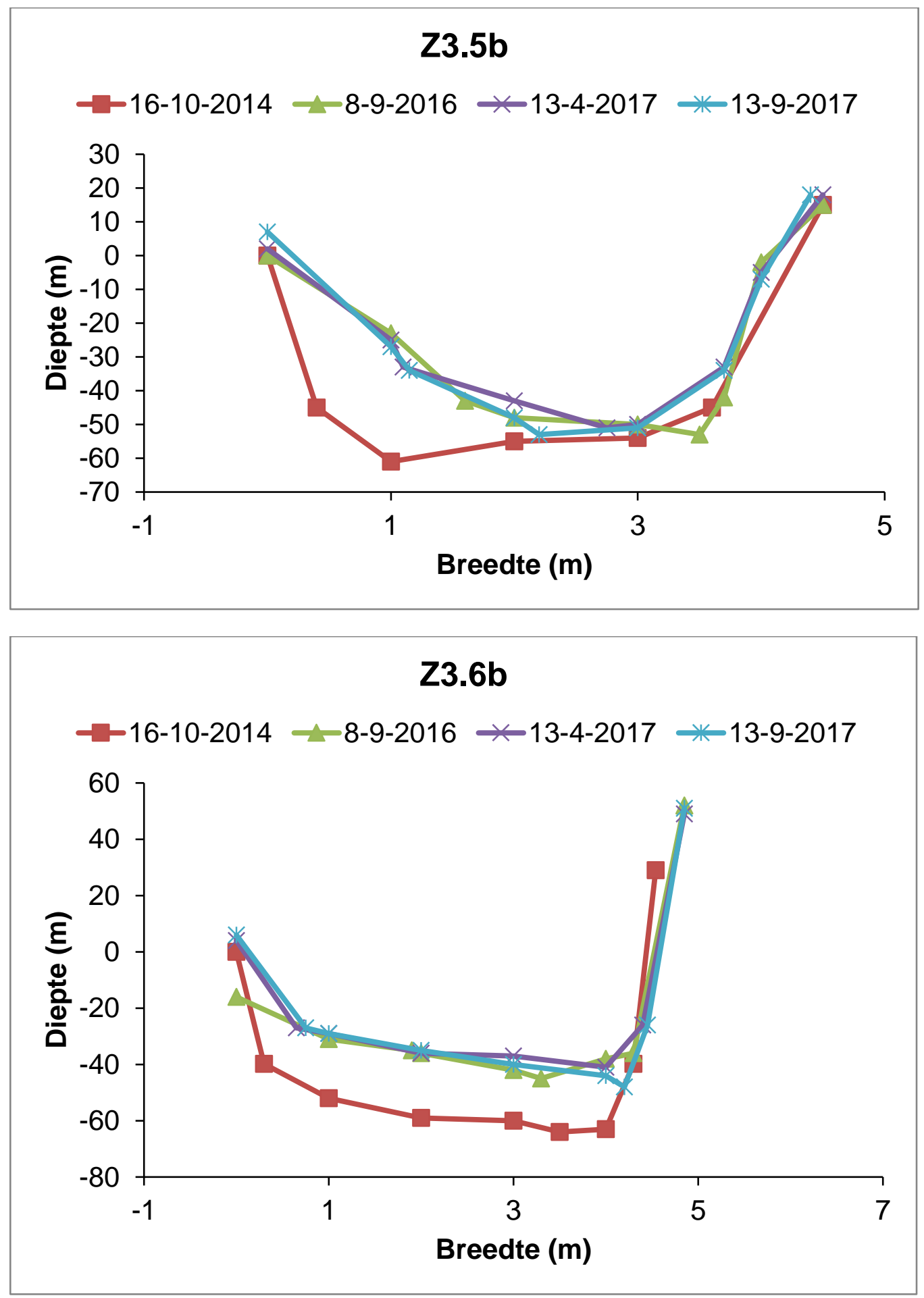

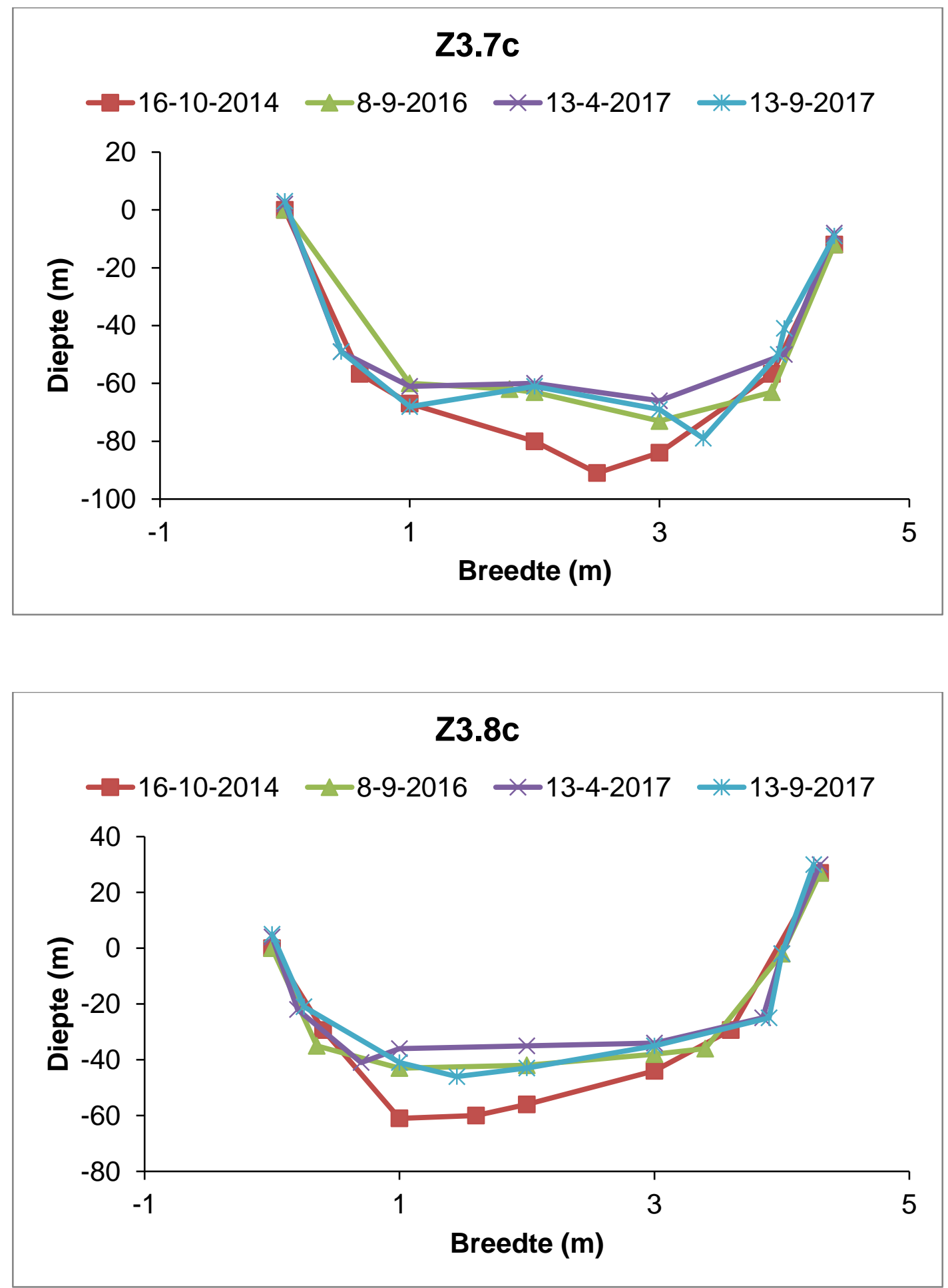


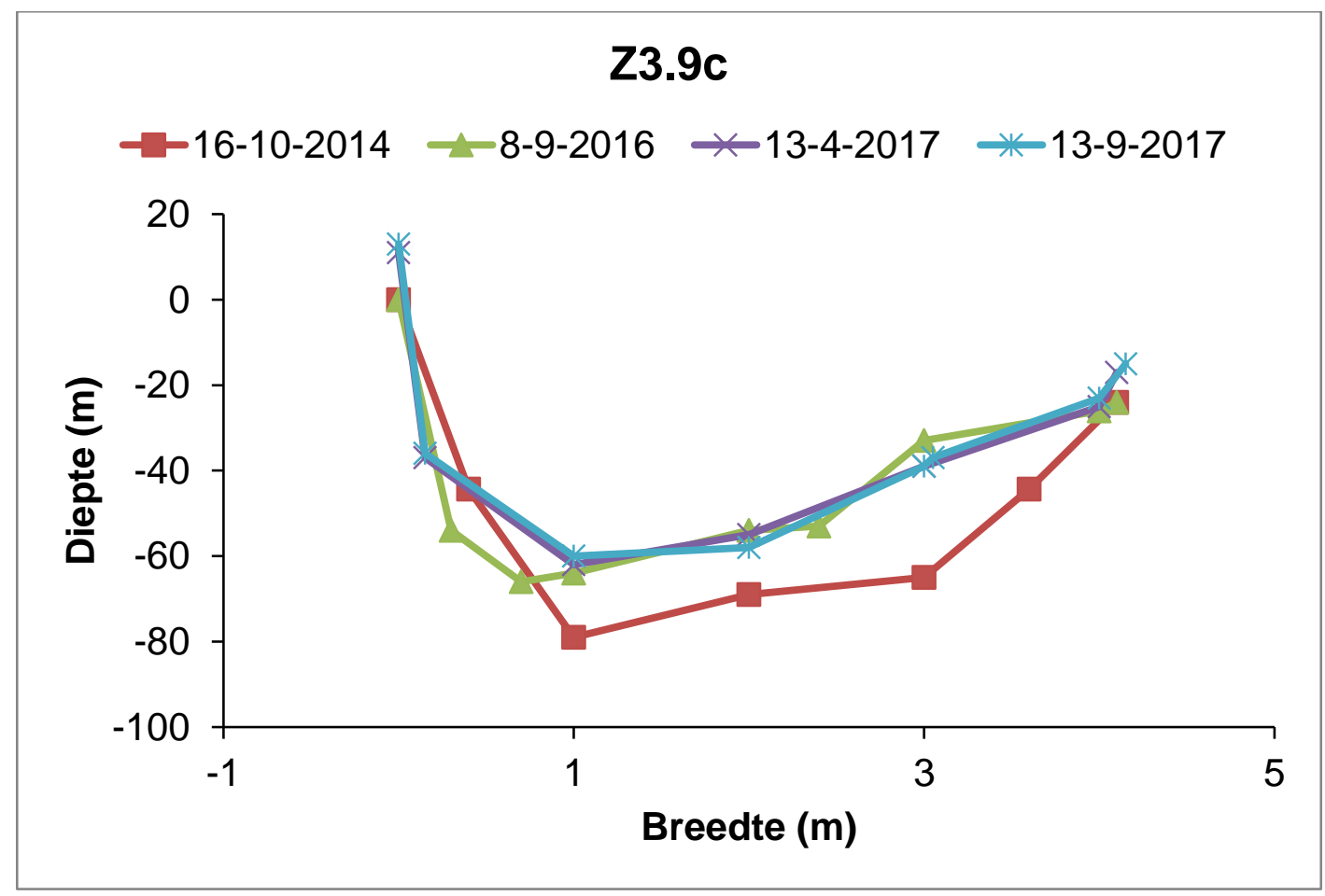

